OPEN ACCESS

Edited by:

Chiaki Ohtaka-Maruyama,

Tokyo Metropolitan Institute of Medical Science, Japan

Reviewed by:

Umberto Di Porzio, Institute of Genetics and Biophysics

"ABT", Italy

Tatsumi Hirata,

National Institute of Genetics, Japan

${ }^{*}$ Correspondence: Paola Squarzoni and Sonia Garel, Brain Development and Plasticity, Ecole Normale Supérieure, 46, rue d'UIm, 75005 Paris, France squarzon@biologie.ens.fr; gare/@biologie.ens.fr

Specialty section This article was submitted to Neurogenesis, a section of the journal Frontiers in Neuroscience

Received: 13 May 2015 Accepted: 30 June 2015 Published: 17 July 2015

Citation:

Squarzoni P, Thion MS and Garel S

(2015) Neuronal and microglial regulators of cortical wiring: usual and novel guideposts.

Front. Neurosci. 9:248. doi: 10.3389/fnins.2015.00248

\section{Neuronal and microglial regulators of cortical wiring: usual and novel guideposts}

\author{
Paola Squarzoni *, Morgane S. Thion and Sonia Garel * \\ Centre National de la Recherche Scientifique UMR8197, Ecole Normale Supérieure, Institut de Biologie, Institut National de la \\ Santé et de la Recherche Médicale U1024, Paris, France
}

Neocortex functioning relies on the formation of complex networks that begin to be assembled during embryogenesis by highly stereotyped processes of cell migration and axonal navigation. The guidance of cells and axons is driven by extracellular cues, released along by final targets or intermediate targets located along specific pathways. In particular, guidepost cells, originally described in the grasshopper, are considered discrete, specialized cell populations located at crucial decision points along axonal trajectories that regulate tract formation. These cells are usually early-born, transient and act at short-range or via cell-cell contact. The vast majority of guidepost cells initially identified were glial cells, which play a role in the formation of important axonal tracts in the forebrain, such as the corpus callosum, anterior, and post-optic commissures as well as optic chiasm. In the last decades, tangential migrating neurons have also been found to participate in the guidance of principal axonal tracts in the forebrain. This is the case for several examples such as guideposts for the lateral olfactory tract (LOT), corridor cells, which open an internal path for thalamo-cortical axons and Cajal-Retzius cells that have been involved in the formation of the entorhino-hippocampal connections. More recently, microglia, the resident macrophages of the brain, were specifically observed at the crossroads of important neuronal migratory routes and axonal tract pathways during forebrain development. We furthermore found that microglia participate to the shaping of prenatal forebrain circuits, thereby opening novel perspectives on forebrain development and wiring. Here we will review the last findings on already known guidepost cell populations and will discuss the role of microglia as a potentially new class of atypical guidepost cells.

Keywords: guidance molecules, glial cells, Cajal-Retzius cells, microglia, axon guidance

\section{Introduction}

Functioning of the mammalian cerebral cortex relies on complex networks of axonal connections between neurons located in specific positions. The initial building of these exquisite circuits occurs during embryonic development and early post-natal days. During this "critical" period, neurons are first generated from spatially restricted proliferative niches and after or while reaching their final destination throughout active migration, extend oriented axons to form synaptic connections with their targets. Cellular migration is hence essential in the first part of brain wiring, because it allocates cells to specific positions and their subsequent settlement and differentiation, leading 
to the emergence of a functional system. In particular, cells can undertake radial or tangential migratory trajectories. During these processes, neurons can migrate locally or far away from their production sites as well as extend local axons or form long-range connections.

Because neurons are generated over a long-time period in the mammalian brain, neuronal migration and axonal navigation occur concomitantly during the constant process of brain development. How are these processes coordinated spatially and temporally to ensure the proper wiring of neural circuits? Over the last decades, this intriguing question has begun to receive answers in a developmental context in which cellular migration and axonal navigation take prominent places, namely the development of the embryonic mammalian forebrain (Borrell and Marin, 2006; Griveau et al., 2010; Villar-Cervino et al., 2013). In distinct regions of the embryonic mammalian forebrain, such as the dorsal cerebral cortex and the ventrally located subpallium, extensive events of radial and tangential migration reallocate neuronal populations and orient axonal navigation. For example, early-born neurons such as Cajal-Retzius cells spread out from different regions of origin to cover all the surface of the cortical primordium; inhibitory interneurons originate from the basal ganglia from which they tangentially migrate to populate the telencephalon; corticothalamic and thalamocortical axons traverse intermediate targets to reach their respective final targets. These events are fundamental to assemble cortical circuits and build the intricate circuitry essential for its functioning. Since defects in migratory processes during embryogenesis have been correlated with the onset of several neurologic and psychiatric diseases, it is crucial to decipher how they are regulated. Besides cells redistribution and morphogenesis, past and more recent studies showed that, throughout neuronal migration, an additional prominent event occurs during forebrain development that is the positioning of molecular cues, which instructs the trajectories of other migrating cells and growing axons. The cells that show these driving properties have different origins, but they share some common characteristics, for which they have been defined as guidepost cells. The purpose of this review is first to provide a definition of the usual concept of guidepost cells, giving an overview of already well-known examples. Moreover, we propose to extend the classical concept of guidepost cells, by speculating on recent findings concerning novel roles of microglia, the macrophages of the brain, in embryonic forebrain wiring.

\section{Toward a "Modern" Definition of Guidepost Cells}

The concept of guidepost cells emerged from the studies on the developing limb bud of the grasshopper embryo (Borrell and Marin, 2006; Griveau et al., 2010; Kwon et al., 2011; VillarCervino et al., 2013). Bate and others described how pioneer projecting axons rely on some intermediate targets positioned along the future axonal path to follow a highly stereotyped pathway (Kwon et al., 2011). These intermediate targets consist of immature neuronal cells that show high affinity for the pioneer growth cones, and that are able, upon direct contact, to stabilize their filopodia and reorient the axonal growth cones on the pathway (Kwon et al., 2011). These important findings laid the foundation of the term "guidepost cells," as located discontinuously along the future axonal trajectory providing short-range cues thereby precisely controlling axonal navigation.

Since these seminal studies, several other cases of guidepost cells have been reported in different organisms and developmental systems (Borrell and Marin, 2006; Griveau et al., 2010; Kwon et al., 2011; Villar-Cervino et al., 2013). To date, the vast majority of the identified guidepost cells in vertebrates belongs to the class of glial cells, such as the radial glia of the optic chiasma (Misson et al., 1988; Guillery et al., 1995; Marcus et al., 1995; Marcus and Mason, 1995; Wang et al., 1995), glial bridges of anterior and postoptic commissures (Silver et al., 1982; Pires-Neto et al., 1998; Barresi et al., 2005; Lent et al., 2005), floor plate cells (Tessier-Lavigne et al., 1988; Bovolenta and Dodd, 1990, 1991; Placzek et al., 1990; Campbell and Peterson, 1993; Kennedy et al., 1994; Serafini et al., 1994, 1996), boundary cap cells (Golding and Cohen, 1997; Fraher et al., 2007), glial cells of the corpus callosum (Silver et al., 1982, 1993; Silver and Ogawa, 1983; Shu and Richards, 2001; Shu et al., 2003a,b). More recently, some populations of tangential migrating neurons have also been discovered to play a guidepost role, with a consequent need to expand the conceptual definition (Sato et al., 1998; Lopez-Bendito et al., 2006; Niquille et al., 2009; Bielle et al., 2011; Hirata et al., 2012). Guidepost cells have been then defined as usually early born, discrete cell populations, with specialized functions that control and regulate axonal navigation, by being located at crucial decision points along the axonal trajectories. These cells can eventually extend an axon along the upcoming path of the tract and, in contrast to other long range-intermediate targets, guideposts act at short range or directly by cell-cell contact. They constitute decisive landmarks for guiding the axons along the correct pathways, which is a fundamental requirement for accurate circuitry assembly. The demonstration of their importance has been highlighted in different systems, by specific cell ablation experiments (Bentley and Caudy, 1983; Sretavan et al., 1995; Del Rio et al., 1997; Sato et al., 1998) and by the use of genetic mutants (Bovolenta and Dodd, 1990; Lopez-Bendito et al., 2006; Bielle et al., 2011), which resulted in aberrant pioneer axonal trajectories (Bielle et al., 2011), eventually with ectopic collateral branches formation (Bentley and Caudy, 1983; Bovolenta and Dodd, 1990) and in failure in axonal progression and in specific axonal innervation (Sretavan et al., 1995; Del Rio et al., 1997; Sato et al., 1998; Lopez-Bendito et al., 2006), respectively. The mechanism by which guidepost cells exert their function in guiding pioneer axonal tracts is throughout the secretion of guidance cues, which can act as attractive or repulsive signals. Both glial cells and tangential migrating guidepost cells have been found to express various families of guidance molecules or adhesion molecules, such as Slits (Erskine et al., 2000; Plump et al., 2002; Shu et al., 2003c), Robos (Bielle et al., 2011), Wnts (Keeble and Cooper, 2006), Neuregulin (Lopez-Bendito et al., 2006), Draxin (Islam et al., 2009), Ephrins (Williams et al., 2003; Mendes et al., 2006) or extracellular matrix proteins (Kuhn et al., 1995; Mandai et al., 
2014). The correct positioning of the same migrating guidepost cells at the intermediate targets along the path is itself instructed by guidance cues (Kawasaki et al., 2006; Nomura et al., 2006; Ito et al., 2008; Bielle et al., 2011). Since these cells act mainly at short range or by cell-cell contact, their proper localisation is fundamental for the subsequent axonal tract development. This has been clearly shown in various guidance molecule mutant models in which altered positioning of guidepost cells led to consequent specific axonal pathfinding defects (Kawasaki et al., 2006; Bielle et al., 2011).

\section{Tangential Migrating Guidepost Cells in the Pathfinding of the Lateral Olfactory Tract}

The Lateral Olfactory Tract (LOT) is the main efferent axonal bundle that conveys the olfactory information from the bulb to several higher olfactory centers in the brain, including the anterior olfactory nucleus, the olfactory tubercle, the piriform and entorhinal cortices and the amygdala (Borrell and Marin, 2006; Griveau et al., 2010; Villar-Cervino et al., 2013) (Figure 1). Indeed, sensory olfactory neurons, residing in the nasal cavities project onto tufted and mitral cells of the olfactory bulb, which in turn extend their axons into the LOT to reach cortical and associated regions. LOT pioneer axons initiate their outgrowth around embryonic day (E) 11.5, followed by the other mitral cells that collectively form the main axonal bundle around E13. Starting from E14.5, LOT axons extend superficial collaterals toward the olfactory cortices and into the other target regions.

Long-range guiding activities are involved in shaping the pathfinding of the LOT. Diffusible repulsive guidance proteins, such as Slit1 and Slit2 derived from the septum, regulate the lateral pathfinding of the mitral cell axons, throughout their receptors, Robo1 and Robo2 (Pini, 1993; Nguyen Ba-Charvet et al., 1999; Nguyen-Ba-Charvet et al., 2002; Fouquet et al., 2007). Some proteins of the Semaphorin class are involved in the growth of olfactory bulb axons (Sema3B) and repulsion of LOT axons (Sema3F) (De Castro et al., 1999; De Castro, 2009). Besides these diffusible long-range signals, it was shown that a peculiar population of cells supplies short-range permissive guidance activity in the formation of the LOT (Sugisaki et al., 1996). These "lot" cells have been identified by the expression of the lot1 antibody (Sato et al., 1998), recently shown to recognize the beta isoform of the metabotropic glutamate receptor subtype1 (mGluR1) (Hirata et al., 2012). Lot cells are the first reported example of migrating neuronal guidepost cells involved in axonal pathfinding and are amongst the first generated neurons in the brain, around E9.5 and E11.5. They have been proposed to have a pallial origin and migrate toward the pallial subpallial boundary (PSB) (Tomioka et al., 2000). Once arrived in the PSB, they change their orientation and extend a long process toward the amygdala region (Kawasaki et al., 2006; Hirata et al., 2012). They correspond to previously identified cells horizontally disposed in the developing PSB (Derer et al., 1977) and their positioning occurs way before the arrival of LOT axons (Sato et al., 1998), for which they constitute a growing substrate. Around E12.5,

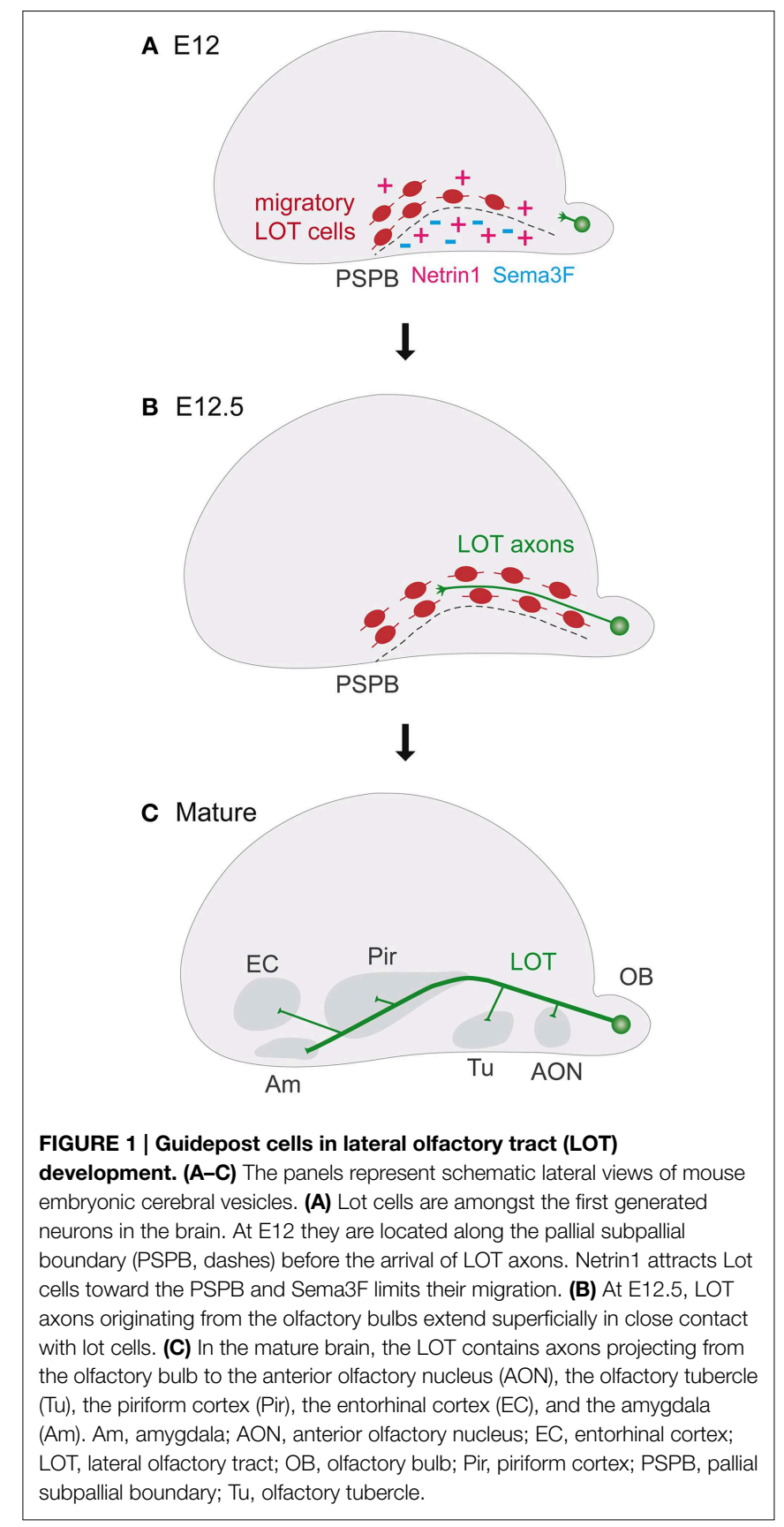

the superficial growing of LOT axons displaces lot cells in the internal border of the path, where they are found subsequently in association with growing collateral axons (Hirata and Fujisawa, 1999). Although initially lot cells where considered as a distinct and unique cell population (Sato et al., 1998), these cells have been recently identified as a subset of Cajal-Retzius (CR) cells, a population of early born cortical neurons, since they share the expression of common molecular markers such as p 73 and Reelin (Dixit et al., 2014).

The role of CR-lot cells as guidepost for the developing LOT tract has been shown throughout toxic ablation experiments by the local use of a neuronal toxin, 6-hydoxydopamine, which 
provokes CR-lot cell death with consequent stall of mitral cell axons in strict proximity (Sato et al., 1998). This role is further highlighted by the analysis of mutant mice that affect this cell population such as Lhx2 (Saha et al., 2007) or Neurog1 and Neurog2 double mutants (Dixit et al., 2014). It has been proposed that lot cells form transient connections with LOT axons, as their final targets in the piriform cortex, amygdala and other higher olfactory centers are not yet mature (Sato et al., 1998; Hirata et al., 2012).

The importance of the proper positioning of CR-lot cells is thus highlighted by their guidepost function to orient LOT axons along their pathway. Still, how these cells act on axons and whether they are required for the progression, channeling or guidance of all axons remains largely to be characterized. By contrast, several guidance cues have been shown to play a role in the positioning of CR-lot cells in the ventral PSB. Netrin1 has been shown to act as an attractant cue for migrating CR-lot cells and participates, in part, to their ventral positioning (Kawasaki et al., 2006). However, in knockout mutant animals for Netrin1 or its receptor $D C C$, only the location of the most ventral CRlot cells resulted affected, associated with specific pathfinding defects on the ventral most LOT axons (Kawasaki et al., 2006). In double Slit1; Slit2 mutants the LOT axonal tract is severely disrupted, with only few axons present in their correct positions. In this context, the proper positioning of CR-lot cells appears to be not drastically affected, thereby revealing that both longrange and local signals cooperate in LOT axonal pathfinding (Fouquet et al., 2007). Another important regulator of the ventral tangential migration of CR-lot cells is the molecule Sema3F that, by the interaction with its specific receptor neuropilin-2 (Nrp-2), confines CR-lot cells on the telencephalic surface (Ito et al., 2008). Sema3F, expressed in the subpallium and cortical plate, acts as a repellent signal, which prevents CR-lot cells to penetrate into deep brain regions, where some are ectopically found in case of Sema3F or Nrp-2 invalidation (Ito et al., 2008). So far, there are not yet reported defects of LOT projections in Nrp-2 mutants (Chen et al., 2000), raising the possibility that these guidepost cells may act locally. Furthermore, since many of these guidance cues can directly act on the axons, additional eventual effects of these genetic invalidations on the pathfinding of LOT axons deserve further analyses.

\section{Cajal-Retzius Cells: Guideposts in the Formation of Entorhino-Hippocampal Projections}

Besides their emerging role in LOT axonal guidance, CajalRetzius cells, together with GABAergic interneurons, have been involved in the development of entorhino-hippocampal projections (Borrell and Marin, 2006; Griveau et al., 2010; VillarCervino et al., 2013). The major afferent excitatory projections in the hippocampus derive from pyramidal neurons in layers II and III of the entorhinal cortex. In particular, layer II pyramidal neurons form axonal connections with the dendrites of the granule cells of the outer molecular layer (OML) of the dentate gyrus (DG), whereas layer III neurons connect mainly with pyramidal cells in the stratum lacunosum-moleculare (SLM) in the cornu ammonis 1 and 3 (CA1 and CA3) (Borrell and Marin, 2006; Griveau et al., 2010; Villar-Cervino et al., 2013). Notably, during brain formation, the entorhinal axons already reach their final positions in the hippocampal regions, before the definitive development of their targets. Indeed, in mouse brain, entorhinal axons arrive in the hippocampus around E15, then they form arborisations in the SLM around E17 and are detected into the OML starting from the first postnatal day (Super and Soriano, 1994; Super et al., 1998; Deng and Elberger, 2001; Deng et al., 2006) (Figure 2). Therefore, even if hippocampal pyramidal neurons and granule cells are generated between E14 and E16, it is only around the second postnatal day that their apical dendrites start to be seen in the SLM, arising as final targets for entorhinal axons (Caviness, 1973; Soriano et al., 1986, 1989; Bayer and Altman, 1987; Super et al., 1998). This process of precise axonal addressing is regulated by Cajal-Retzius cells, which, as in LOT formation, have been reported to regulate axonal outgrowth. Cajal-Retzius (CR) cells are early born neurons, which are produced at E9-11 by focal pallial sources, including cortical hem, septum, PSB, and thalamic eminence (Grove et al., 1998; Meyer et al., 1999, 2002; Meyer and Wahle, 1999; Hevner et al., 2003; Takiguchi-Hayashi et al., 2004; Bielle et al., 2005; Cabrera-Socorro et al., 2007; Tissir et al., 2009; Ceci et al., 2010; Meyer, 2010; Gu et al., 2011; MartinezCerdeno and Noctor, 2014). CR cells migrate tangentially from their sources in the marginal zone of the cerebral cortex and rapidly cover the entire sheet. Their marginal localization and migration is regulated by CXCL12 produced by the meninges, which acts through CXCR4 and CXCR7 receptors (Borello and Pierani, 2010; Trousse et al., 2014). The marginal maintenance of $\mathrm{CR}$ cells also requires radial glia integrity, as revealed by

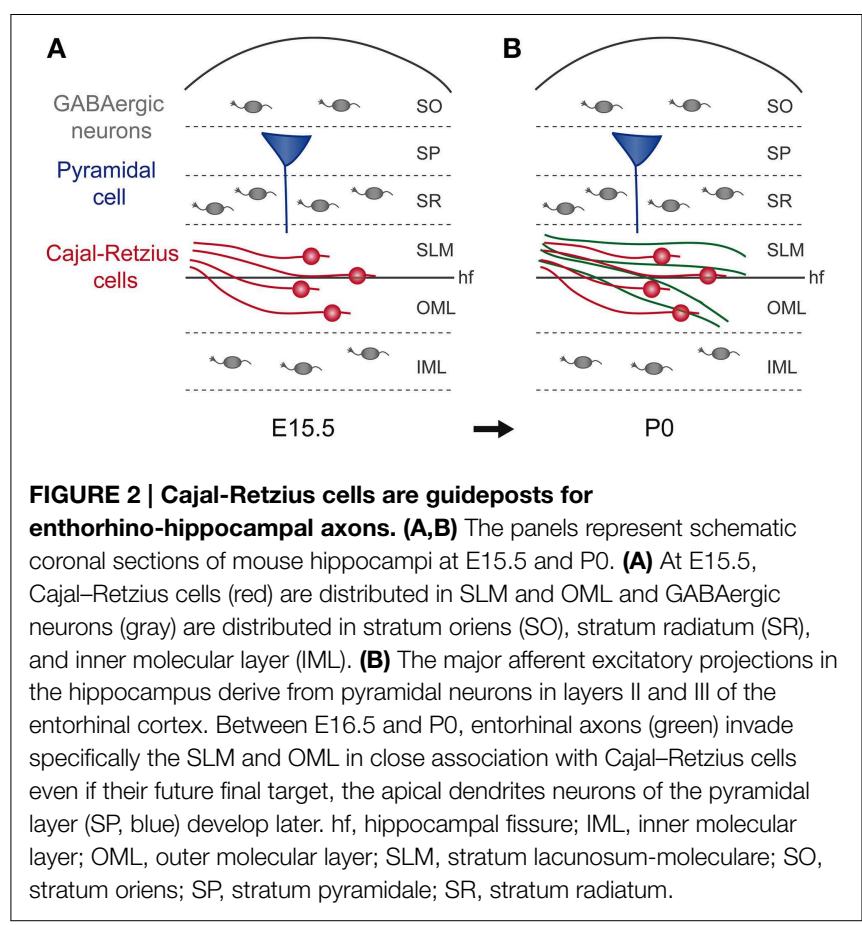


analysis of $\beta 1$ integrin conditional knockout (Kwon et al., 2011). In parallel, interactions between CR cells or with surrounding structures have been shown to control their random dispersion and distribution by Eph/ephrin-dependent contact repulsion or PlexinD1 signaling (Villar-Cervino et al., 2013; Bribian et al., 2014). Such migratory behaviors enable CR cells of different sources to preferentially cover cortical regions (Griveau et al., 2010; Gu et al., 2011). Functionally, CR cells have been shown to regulate cortical layering, neuronal and radial glia morphology, and cortical regionalisation, via the production of the secreted glycoprotein Reelin or additional membrane-bound or secreted factors (Borello and Pierani, 2010; Griveau et al., 2010; GilSanz et al., 2013; Trousse et al., 2014). In the hippocampus, as the structure folds during development, CR cells localize in the future SLM and OML (Takiguchi-Hayashi et al., 2004; Bielle et al., 2005; Yoshida et al., 2006). Using electron microscopy, it has been shown that during embryogenesis pioneer entorhinal axons form transient synaptic contacts with Cajal-Retzius cells in SLM and OML, the future regions that will host pyramidal and granule cells apical dendrites (Super et al., 1998). Moreover, in organotypic culture experiments, this interaction has been shown to be fundamental for the growth of entorhinal axons in the hippocampus (Frotscher and Heimrich, 1993; Li et al., 1993; Frotscher et al., 1995; Del Rio et al., 1997). Indeed, eliminating CR cells from cultured slices with the local toxin 6-hydoxydopamine avoided entorhinal axonal growing in the hippocampus (Del Rio et al., 1997). These experiments therefore constituted a strong evidence of the role as placeholders for CR cells in the formation of entorhino-hippocampal connections (Forster et al., 1998). About the molecular cues that could be involved in entorhinal axon guidance by CR cells, the most obvious candidate could be the glycoprotein Reelin, of which CR cells constitute the main source (D'arcangelo et al., 1995, 1997; Hirotsune et al., 1995; Ogawa et al., 1995; Tissir and Goffinet, 2003). It has been previously shown that Reelin controls cortical layering, organization and the orientation of radially migrating neurons (Borello and Pierani, 2010; Frotscher, 2010; Griveau et al., 2010; Martinez-Cerdeno and Noctor, 2014). Nevertheless, antibody-mediated blocking of Reelin in ex vivo co-cultures of hippocampal slices and entorhinal tissue, does not lead to dramatic defects in entorhinal axonal pathfinding. However, fewer entorhinal fibers reach the hippocampal layers, developing shorter axonal branches. These findings have been confirmed in vivo in reeler mice, a natural Reelin mutant, which presents severe defects in cortical lamination. Similarly to co-cultures experiments, the absence of Reelin had no dramatic effects about entorhinal axonal ingrowth or targeting, but entorhinohippocampal axonal terminations appear thinner than in control animals. Moreover, these defects are transient, since then in reeler adult mice a normal branching density is observable (Frotscher and Heimrich, 1993; Li et al., 1993; Frotscher et al., 1995; Del Rio et al., 1997; Borrell et al., 1999; Deller et al., 1999). Altogether, these results confirm the important role of CR as guidepost cells in entorhino-hippocampal innervation and reveal reelin as an important factor for branching, collateral formation and synaptogenesis of entorhinal axons. However, they leave still an open question about additional molecular cues involved in the pathfinding of entorhinal axons in the hippocampus.

\section{En Route to the Cortex: Guidepost Cells Open a Path for Thalamocortical Connections}

Mammalian neocortex forms connections with the rest of the brain via the internal capsule, which includes bundles of corticofugal efferent axons and reciprocal afferent thalamocortical projections, which convey sensory and motor information to the neocortex. In the context of axonal pathfinding, the development of the internal capsule has been extensively studied (Molnar et al., 2012; Garel and LopezBendito, 2014). Indeed, this system has a major physiological relevance, but also allows a variety of experimental approaches, due to its important size and extension in the developing brain.

During the years, many findings had contributed to elucidate the routes and the molecular mechanisms that shape thalamocortical and corticofugal connection paths. In mouse development, these important axonal systems start to form during early/mid gestation. Thalamocortical axons (TCAs) originate from neurons located in the thalamus, grouped in distinct nuclei, showing a topographic organization that corresponds to the spatial innervation of different cortical areas (Molnar et al., 2012; Garel and Lopez-Bendito, 2014). From E12 to E15, TCAs extend ventrally, crossing the prethalamus, and traverse the diencephalic/telencephalic boundary, entering the subpallium at the level of the internal capsule. At E14, early TCAs reach the PSB, where they encounter the reciprocal pioneer corticothalamic axons (CTAs). Subsequently, from E14.5 to E18.5, TCAs form transient connections with subplate cells residing in their respective target cortical areas. After this waiting period, TCAs send collaterals into the cortical plate and finally establish thalamocortical connections (Figure 3). Meanwhile, corticofugal axons grow along the same path of TCAs and split in CTAs and in corticosubcerebral axons that proceed toward other subcortical regions. This reciprocal wiring has been shown to be tightly controlled, in part by guidepost cells, transient axonal populations and several structures that have been shown to act as milestones along the path.

Chronologically, pioneer cortical subplate neurons have been firstly proposed as guidepost cells in regulating the entering and progression of TCAs into the cortical plate (Garel and Lopez-Bendito, 2014; Hoerder-Suabedissen and Molnar, 2015). These observations have been strongly supported by several experimental evidences. To date, in the visual cortex, subplate neurons ablation avoids the entering of the corresponding thalamic geniculocortical axons (Ghosh et al., 1990; Ghosh and Shatz, 1993). In mutant mice, such as reeler, $p 35^{-/-}$and $c d k 5^{-/-}$ that present subplate cells in the marginal zone, due to severe defects in preplate splitting, TCAs form abnormal projections to connect with the ectopic subplate in the marginal zone. Since the discovery of subplate cells, other groups of cells have been found to exert a role of guidepost for TCAs. In mouse, early born cells, named perireticular cells, have been identified in the 


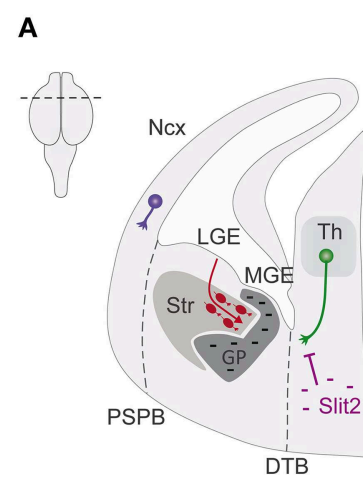

$\mathrm{E} 12$

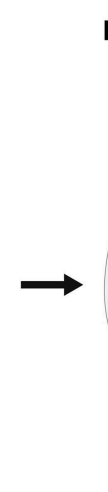

B

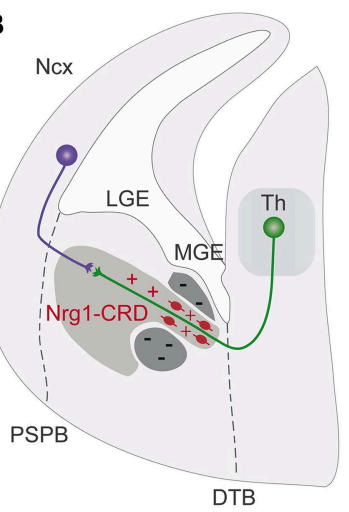

E14

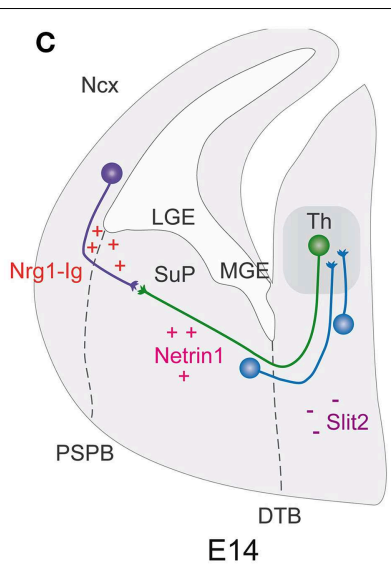

E14
D

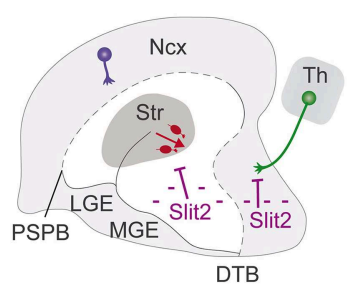

E12
E



E14
FIGURE 3 | Corridor neurons shape the internal pathfinding of thalamocortical axons. (A-C) Schematic representation of hemicoronal sections of mouse embryonic telencephalons. (D,E) Schematic representation of median sagittal views of mouse embryonic telencephalons. (A,D) At E12, tangentially migrating LGE-cells (red), repelled by Slit2, form in the MGE a permissive corridor for thalamocortical axons. Thalamocortical axons (green), repelled by hypothalamic Slit2, turn to enter the MGE. (B,E) At E14, pioneer thalamocortical axons grow through the permissive corridor (red cells) and the Str, where they encounter the reciprocal pioneer corticothalamic axons (purple). Guidance cues including Slits, Netrin1, Nrg1-IG, Ng1-CRD present along the pathway, orient the axons. (C) Thalamocortical axons (green) extend from the dorsal thalamus (Th) toward the neocortex (Ncx), crossing the diencephalic-telencephalic boundary (DTB, black dashes), and enter the subpallium (SuP) at the level of the internal capsule. At E14, thalamocortical axons reach the pallial subpallial boundary (PSPB, black dashes), where they encounter the reciprocal pioneer corticothalamic axons (purple). Thalamocortical axon guidance is regulated by different cellular and molecular actors: prethalamus (blue) and SuP cells sending an axon to the Th; the repellent Slit2 in the hypothalamus, the attractant Netrin1 in the SuP, Nrg1-Ig in the neocortex. DTB, diencephalic-telencephalic boundary; GP, globus pallidus; LGE, lateral ganglionic eminence; MGE, medial ganglionic eminence; Ncx, neocortex; PSPB, pallial subpallial boundary; Str, striatum; SuP, subpallium; Th, dorsal thalamus. future path of the internal capsule, which at E12.5 send a cellular process to the thalamus. The hypothesized role of these cells is to provide a cellular scaffold for the future TCAs and CTAs, which is consistent with several experimental evidences (Mitrofanis, 1992, 1994; Mitrofanis and Baker, 1993; Mitrofanis and Guillery, 1993; Adams and Baker, 1995; Metin and Godement, 1996; Molnar et al., 1998b; Braisted et al., 1999; Molnar and Cordery, 1999). In effect, different defects in TCA pathfinding have been reported in mutant mice presenting absence, reduction or displacement of perireticular cells (Tuttle et al., 1999; Bishop et al., 2000, 2003; Lopez-Bendito et al., 2002; Lakhina et al., 2007). Unfortunately, the current absence of specific molecular markers and the wide distribution of these cells experimentally limit the investigation about their origin and function.

More recently, another population of guidepost cells has been observed in the subpallium, which comprises the lateral and medial ganglionic eminences (LGE and MGE). These cells are GABAergic LGE derived-neurons that tangentially migrate in the MGE, forming a permissive corridor, in an otherwise not permissive territory, for the growth of TCAs along an internal path toward the cortex (Lopez-Bendito et al., 2006). Because of their function, they have been named "corridor" cells; they are located in the MGE, in which they migrate from E11.5 to E14, but express LGE molecular markers, such as Islet1, Ebf1 and Meis2. By gain-of-function experiments in cultured organotypic embryonic brain slices and by the use of full or conditional mutant mice of ErbB4 and Neuregulin1 respectively, it has been revealed that corridor cells, via the expression of Neuregulin1, provide a permissive corridor for TCAs, which express the corresponding ErbB4 receptor (Lopez-Bendito et al., 2006). How are corridor cells positioned? A ventral repulsive activity from the subpallium, mediated by Slit2 and Robo1 and Robo2 respective receptors, has been shown to limit, in vitro, ex vivo, and in vivo, the ventral tangential migration of corridor cells, playing a role in the formation of corridor shape. Indeed, Slit2 inactivation leads to abnormal ventral migration of corridor cells, with aberrant corridor shaping and consequent defects on TCAs pathfinding (Bielle et al., 2011). These findings constitute a starting point 
for further investigations on the origin, specification and fate of corridor cells.

In addition to guidepost cells, several important structures and molecules present in the subpallium or prethalamus have been shown to play critical roles in the guidance of both TCAs and reciprocal CTAs (Metin and Godement, 1996; Braisted et al., 1999; Garel et al., 1999; Sussel et al., 1999; Marin et al., 2002; Marin and Rubenstein, 2002; Yun et al., 2003). For instance, knockout mutation analyses, have highlighted the importance of classical guidance cues and their receptors, such as Slit1, Slit2, Robo1, Robo2, Netrin1, and Sema6A, for the local regulation of TCAs guidance (Braisted et al., 2000, 2009; Leighton et al., 2001; Bagri et al., 2002; Bonnin et al., 2007; Lopez-Bendito et al., 2007; Powell et al., 2008; Little et al., 2009). Other important regulators are the members of the protocadherin family, which have been shown to be important for both TCAs and CTAs progression into the subpallium (Wang et al., 2002, 2006; Tissir et al., 2005; Uemura et al., 2007; Zhou et al., 2008, 2009; Qu et al., 2014). For instance, inactivation of OL-protocadherin was shown to impair the subpallial crossing of TCA associated with defects in striatal axonal outgrowth (Uemura et al., 2007). In addition, mutant mice with constitutive or specific inactivation of Celsr3 in the prethalamus and subpallium present similar impairments, which consist in the stall of TCAs in the ventral subpallium, across the diencephalic/telencephalic boundary, and in CTAs arrest in the proximal part of the LGE, suggesting a possible cooperation of these two factors in the process (Tissir et al., 2005; Zhou et al., 2008, 2009; Qu et al., 2014). Strikingly, these phenotypes are almost phenocopied by deletion of Frizzled3, which is associated with Celsr signaling pathway (Wang et al., 2002, 2006). Last, but not least, the expression of the transmembrane protein Linx is required on subplate cells, subpallium and prethalamaus guideposts, for the progression of TCAs and CTAs revealing a role for this molecule in axon/axon interactions and potentially guideposts/axons interactions (Mandai et al., 2014). More generally, it will be essential to precise which of the aforementioned guidance cues regulates the positioning and/or function of guidepost cells located along the internal capsule path.

In addition to delineating an internal trajectory for TCAs, guidepost neurons have been shown to play additional roles in thalamo-cortical wiring. First, there is now solid evidence that TCAs and CTAs interact to form reciprocal connections, as proposed by the handshake hypothesis (Blakemore and Molnar, 1990; Molnar and Blakemore, 1991, 1995; Chen et al., 2012; Molnar et al., 2012; Deck et al., 2013; Garel and Lopez-Bendito, 2014). As such, guideposts that shape TCAs path have an indirect impact on the guidance of reciprocal CTAs. Second, while TCAs originating from principal thalamic nuclei all grow internally in the corridor, they adopt distinct rostrocaudal positions in the capsule, depending on their nucleus of origin and their cortical target (Molnar et al., 1998a, 2012; Garel and LopezBendito, 2014). This topographic ordering has been shown to depend on local subpallial positional information (Dufour et al., 2003; Bonnin et al., 2007; Wright et al., 2007; Powell et al., 2008; Bielle et al., 2011; Demyanenko et al., 2011a,b; Lokmane et al., 2013). Indeed, guidance factors such as Slit1 and Netrin1 (and their combinatorial activity), Sema3A, ephrinAs, as well as L1, CHL1 participate to the topographic ordering of TCAs deriving from different thalamic nuclei, with a dramatic impact on their final cortical addressing (Bonnin et al., 2007; Wright et al., 2007; Powell et al., 2008; Bielle et al., 2011; Demyanenko et al., 2011a,b; Lokmane et al., 2013). Remarkably, positional information has been shown to be present already in the corridor, as TCAs enter the subpallium (Bielle et al., 2011). Accordingly, the aforementioned guidance factors are present in the corridor, especially Slit1, supporting the idea that they act as TCAs grow internally (Bielle et al., 2011). Importantly, altering the ordering of TCAs in the subpallium by genetic manipulation has been shown to impair the fine topography of TCAs in the somatosensory cortex (Lokmane et al., 2013; Lokmane and Garel, 2014). These experiments reveal that in addition to cortical signals, intermediate ordering of axons, in part by corridor cells, is important for fine-grained topography of TCAs. Together, such recent studies highlight additional roles of corridor internal guideposts in reciprocal and topographical wiring.

\section{Microglia Cells: Novel Unusual Guidepost Cells?}

Microglia are the resident macrophages of the brain, which control brain homeostasis in physiologic conditions and constitute the first line of defense in case of diseases and against pathological threats. Initially described by Del RioHortega (1932), the physiological functions and the origin of these cells have been remained controversial for a long time. Until recently, most studies focused on the roles of microglia in brain damage and diseases and in their participation to neuro-inflammatory processes via the release of neurotrophic and pro-inflammatory factors as well as the ability to perform phagocytosis. Over last decade, several landmark studies have revealed that, using conserved cellular mechanisms, microglia contribute to normal brain functions. Indeed, microglia have been shown to modulate synaptic transmission, to regulate synaptic formation and elimination, and to shape postnatal and embryonic brain circuits as reviewed in Paolicelli and Gross (2011), Schafer et al. (2013), Bilimoria and Stevens (2014), Katsumoto et al. (2014), Paolicelli et al. (2014), Salter and Beggs (2014) and Casano and Peri (2015). Below, we will focus on specific features of microglia during early brain wiring that bear similarities with those of guideposts cells, such as their capacity to act at short range, their early origin and focal positioning as well as the production of several molecular factors by which they can interact with and condition their surrounding neural environment.

\section{Microglia Survey and Interact with Their Local Environment}

In the last decade, technological advancements such as twophoton laser scanning microscopy, allowed the observation of microglia behavior in vivo, in normal conditions. Ramified microglia, initially thought to be in a resting state in opposition to the activated, amoeboid morphology observed following brain injury, were found to be extremely active in 
surveying their environment. Indeed, very frequent extensions and retractions of microglia ramifications were observed in contact with neighboring neuronal cells, astrocytes and blood vessels; furthermore their extensions were increased by changes in both neuronal activity, blood vessel lesions and ATP variation levels in vivo (Davalos et al., 2005; Nimmerjahn et al., 2005). Processes of "resting microglia" were found to interact with synapses in somatosensory and visual neocortex, forming direct appositions with different synaptic elements. In particular, morphological changes of microglia processes, with the appearance of phagocytic structures and modifications of synaptic apposition frequencies were shown to be modulated by variation in visual experience (Wake et al., 2009; Tremblay et al., 2010). Following similar lines, microglia were found to modulate neuronal activity (Li et al., 2012; Pascual et al., 2012). For instance, in zebrafish larvae optic tectum, microglia were shown to contact highly activated neurons for longer time, correlating with a subsequent decreased neuronal activity (Li et al., 2012). Conversely, microglia activation in vitro by LPS stimulation was reported to indirectly increase the frequency of spontaneous synaptic AMPAergic post-synaptic currents in hippocampal neurons (Pascual et al., 2012). Such findings have fundamentally changed our conception of microglia by revealing that these cells exert the capacity to act at short-range on their surrounding neural environment. Since then, besides their immune-defensives functions, these cells have started to be considered as active modulators during healthy brain development and maturation as well as actors of pathologic brain wiring and functioning.

\section{Early Origin of Microglia}

Originally thought to arise form peripheral bone marrow derived-macrophages that invade the brain after birth, microglia have been show, throughout series of fate-mapping experiments, to originate from yolk sac myeloid progenitors and to be dependent on Pu.1, Irf8 (Kierdorf et al., 2013) and colonystimulating factor 1 receptor (CSF1R) (Ginhoux et al., 2010, 2013; Erblich et al., 2011; Schulz et al., 2012; Gomez Perdiguero et al., 2013; Kierdorf et al., 2013; Hoeffel et al., 2015). In mice, yolk sac derived-microglia precursors migrate into the neural folds during embryogenesis and, by in situ proliferation, generate microglia that populate the adult brain. Under normal conditions, microglia comprise resident cells since the infiltration of peripheral monocytes or macrophages into the CNS is limited by the blood-brain barrier (Mildner et al., 2007; Ginhoux et al., 2010; Schulz et al., 2012; Gomez Perdiguero et al., 2013). Thus, microglia enter the brain from early prenatal stages and form an autonomous, self-sustained population. Remarkably, colonization of embryonic brain tissues by microglia appears to be a highly conserved process across vertebrate species (Perry et al., 1985; Ashwell, 1991; Cuadros and Navascues, 2001; Herbomel et al., 2001; Verney et al., 2010; Schlegelmilch et al., 2011; Swinnen et al., 2013), suggesting that embryological "seeding" of the microglial population may be also conserved.

How is the number or density of microglia regulated? Different embryonic or postnatal methods have been reported for the ablation of microglia in vivo or in cultured brain slices (Duffield et al., 2005; Heppner et al., 2005; Varvel et al.,
2012; Ueno et al., 2013; Elmore et al., 2014; Squarzoni et al., 2014). Among those methods, pharmacologic depletion models acting on CSF1R signaling, revealed that after birth, a complete microglia repopulation occurs in a 1-week time window (Elmore et al., 2014; Squarzoni et al., 2014). These results show that there is a homeostatic control over the microglial population and raise the questions of the underlying mechanisms. While the origin of these repopulating cells is still debated, it has been shown for the adult repopulation that a local brain pool of nestin-positive cells differentiates into microglia thereby restoring their usual number (Elmore et al., 2014). Collectively, these essential findings match some forward-looking theories formulated by del Rio Hortega, which postulated that microglia enter the brain during embryogenesis (Del Rio-Hortega, 1932); at the same time, they highlight how the constant presence of microglia within the brain is tightly regulated.

\section{Microglia in Defining the Number of Neurons: Neurogenesis and Survival}

Microglia have been recently shown to take part to several important events which contribute to shaping of neural circuits, including neurogenesis, neuronal survival, synaptic remodeling and maturation. The role in neurogenesis and survival has been examined in both the adult niche and the developing brain. For instance, in adult murine hippocampus, unchallenged microglia regulate by phagocytosis the number of immature neurons maintained in the subventricular zone, one of the few sites of postnatal neurogenesis (Sierra et al., 2010, 2013). In macaque and rat neocortex, alteration of microglia activity by maternal immune activation through LPS, Doxycycline treatment or microglia elimination by Liposomal clodronate exposition, significantly affects the number of neuronal precursors in the embryonic and postnatal brain (Cunningham et al., 2013).

In parallel, microglia have been also reported to regulate neuronal number by active induction of apoptosis, or oppositely to contribute to neuronal survival, in different regions of the brain. For instance, early postnatal apoptosis in the cerebellar Purkinje cell (PC) population was shown to be induced by superoxide ions generated from microglial respiratory bursts (Marin-Teva et al., 2004). These results provided support to previous studies showing that the depletion of microglia in brain culture slices in vitro resulted in increased PC survival (Van Rooijen et al., 1997). Likewise, in perinatal mouse hippocampus, microglia was found to enhance hippocampal neuronal apoptosis by the CD11b/DAP12 integrin signalingdependent production of reactive oxygen species (Wakselman et al., 2008). Conversely, microglia have been shown to actively sustain postnatal cell survival of layer $\mathrm{V}$ cortical neurons in mouse by the production of the trophic factor IGF1 (Ueno et al., 2013). Indeed, postnatal microglia inactivation by minocycline, microglia temporal elimination in CD11b-DTR transgenic models, as well as the use of IGF1R inhibitors and igf1 siRNA, resulted in increased cell death of layer V cortical neurons (Ueno et al., 2013). Altogether, these findings show that microglia regulate the number of neurons produced and maintained in the brain, through a balanced 
activity on progenitors, immature neurons and maturing neurons.

\section{Microglia Shape the Postnatal Brain: Synapse Formation and Synapse Pruning}

Besides their roles on neurogenesis and neuronal cell homeostasis, microglia have been found to contribute to synaptogenesis, synaptic remodeling and brain maturation. Similarly to IGF1 for layer V cortical neurons, the production of the neurotrophin BDNF by microglia has been shown to promote synapse formation via signaling to its cognate receptor TrkB. Remarkably, specific microglia or microglia-BDNF depletion, using CX3CR1 ${ }^{C r e E R}$ mice, both lead to deficits in multiple learning tasks and learning-induced synaptic remodeling (Parkhurst et al., 2013). These major findings highlight the ability of microglial cells to impact on the building and homeostasis of neural circuits throughout the very local active production of secreted factors.

In addition, microglia were shown to play an active role in postnatal synaptic pruning, contributing to the shaping and maturation of the brain, by their close spatial and temporal contact with synapses (Paolicelli et al., 2011; Schafer et al., 2012, 2013; Kettenmann et al., 2013). In particular, this has been directly observed in the retinogeniculate system, where surrounding microglia participate to the activitydependent synaptic remodeling, eliminating the weaker presynaptic connections through a C3/CR3 complementdependent mechanism (Schafer et al., 2012, 2013). Similarly, in the hippocampus microglia were found to contribute to synaptic refinement. Specifically, the CX3CR1/fractalkine signaling pathway plays a central role in microglia/synapses communication, since $C \times 3 \mathrm{cr} 1^{-/-}$mice show temporal reduction of hippocampal microglia number, leading to a deficit in synaptic pruning. Consistently, with early defects in synaptic communication, these mice were shown to exhibit reduced functional brain connectivity, together with social interaction and behavioral deficits (Paolicelli et al., 2011; Zhan et al., 2014). In the somatosensory neocortex, reduced density of microglia cells of $\mathrm{C} x 3 \mathrm{cr}^{-/-}$mice due to a delay in recruitment of these cells, has been shown to impact on the maturation of thalamocortical synapses (Hoshiko et al., 2012). Thus, the density of these cells, their proper functioning, as well as their capacity to specifically perform local phagocytosis or production of secreted factors, constitutes an important factor for sculpting postnatal brain circuits.

\section{Microglia in the Embryonic and Perinatal Brain: the Importance of Spatial and Temporal Positioning}

What about a role of microglia during embryogenesis? In contrast to their later homogeneous distribution in the adult brain, embryonic, and perinatal microglia show an uneven distribution in different species (Ashwell, 1991; Verney et al., 2010; Arnoux et al., 2013; Cunningham et al., 2013; Swinnen et al., 2013; Squarzoni et al., 2014). In particular, in the mouse, round or more ramified microglia have been observed in different focal hotspots, which are not particularly related to apoptosis, whereas some zones, such as the cortical plate is largely devoid of microglial cells (Ashwell, 1991; Verney et al., 2010; Cunningham et al., 2013; Swinnen et al., 2013; Squarzoni et al., 2014). More in depth analyses revealed that microglia accumulations correspond to important decision landmarks in axonal paths or cellular migratory routes. In particular, discrete groups of microglia associate with the corpus callosum, the external capsule or establish a contact with incoming dopaminergic axons in the ventral telencephalon. Specific associations with progenitor zones have also been observed in mice and other mammals, potentially regulated by chemokine production by these progenitors (Cunningham et al., 2013; Arno et al., 2014).

Pharmacologic or genetic ablations of microglia have been used to probe the roles of these cells during embryonic brain wiring (Figure 4). Together with maternal immune activation (MIA) and genetic microglial impairment $\left(\mathrm{C} \times 3 \mathrm{crl}^{-/-}\right)$, these studies showed that microglia regulate the outgrowth of dopaminergic axons, thereby revealing the importance of the precise spatial-temporal microglia localisation (Squarzoni et al., 2014). In addition, microglia contribute to the development of the Corpus Callosum (CC), the largest commissural structure between the cerebral hemispheres (Pont-Lezica et al., 2014). Indeed, genetic functional impairment of microglia (Dap12-/-) or developmental functional alteration by MIA, down-regulate the expression of genes related to neuritogenesis in microglia, with a consequent impairment on the $\mathrm{CC}$ fasciculation in these mouse models. A similar CC fasciculation phenotype has been equally observed in the genetic model of microglia ablation, $P u \cdot 1^{-/-}$(Pont-Lezica et al., 2014). Together these studies suggest that the spatial and temporal positioning of embryonic microglia modulates the development of specific and important axonal tracts. The underlying cellular and molecular mechanisms still remain to be deciphered.

In addition, microglia, which show a timely invasion of the cortical plate (CP) (Cunningham et al., 2013; Swinnen et al., 2013; Squarzoni et al., 2014) were found to regulate the assembly of cortical circuits. Cortical circuits are formed by an intricate network of a majority of excitatory neurons and a minority of functionally important inhibitory interneurons (Marin and Rubenstein, 2003; Sur and Rubenstein, 2005; Batista-Brito and Fishell, 2009; Cossart, 2011; Fishell and Rudy, 2011; Rico and Marin, 2011; Rubenstein, 2011; Marin and Muller, 2014). Indeed, various classes of interneurons shape the network output and interneuron dysfunction as well as defects in the excitation/inhibition balance have been associated with several neurodevelopmental disorders such as Autism Spectrum Disorders (ASD) or Schizophrenia. As aforementioned, microglia regulate the number of neuronal precursors in the subventricular zones of the neocortex (Cunningham et al., 2013) and are firstly excluded from the CP, which they invade after E16.5, remaining initially confined to the deeper layers (Swinnen et al., 2013; Squarzoni et al., 2014). Absence, immune activation or genetic impairment of microglia were found to impact on the laminar distribution of a specific population of interneurons that express the transcription factor Lhx6. Indeed, in absence of microglia (pharmacological 
A

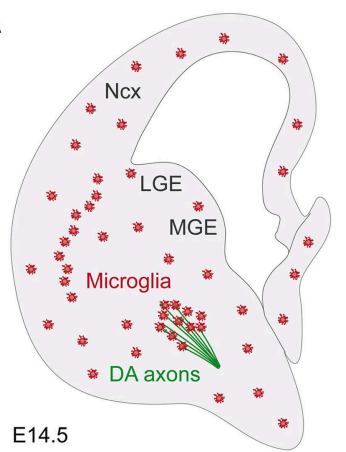

control

\section{D}

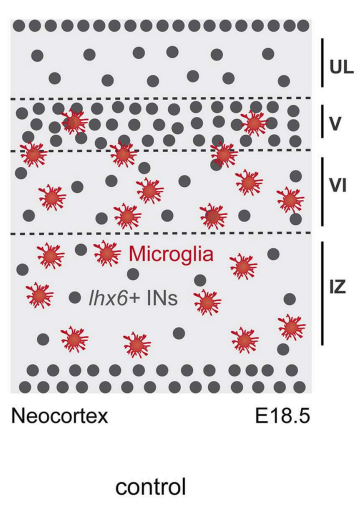

B

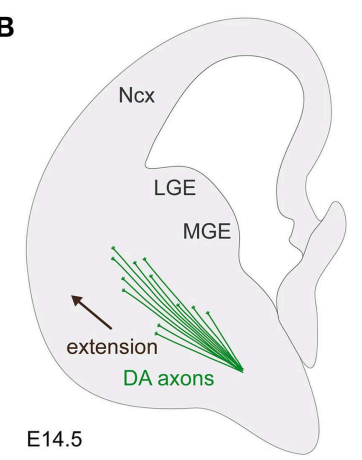

microglia depletion

Pu. $1^{\%}$

cx $3 \mathrm{cr}^{-1}$

\section{E}

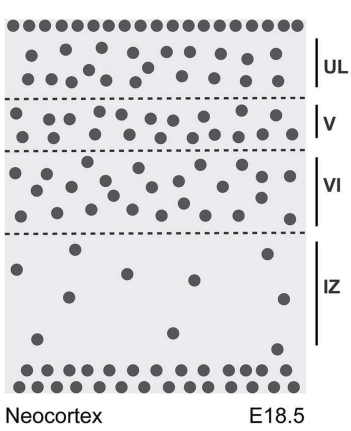

C

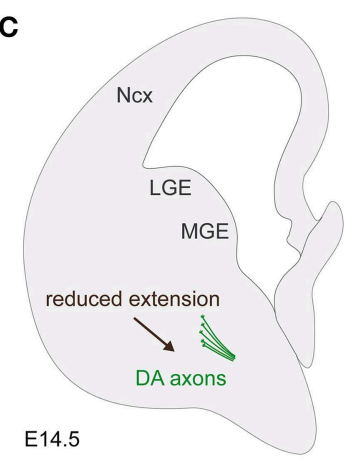

maternal immune activation

F

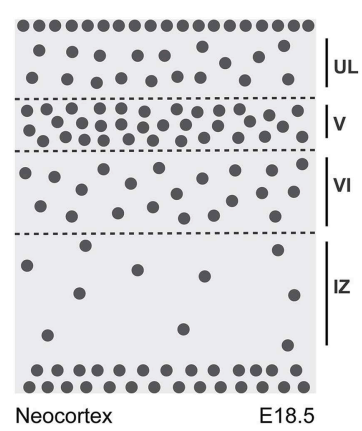

maternal immune activation dap $12^{-1-}$
FIGURE 4 | Microglia in the outgrowth of dopaminergic axons and the positioning of cortical interneurons. (A-C) Schematic

representations of coronal hemisections of E14.5 mouse embryonic brain. (D-F) Schematic representations of E18.5 coronal sections through the somatosensory neocortex of mouse embryonic brain. (A) At E14.5, microglia (red) establish a contact with dopaminergic axons (green) entering in the ventral telencephalon. (B) Pharmacologic or genetic cellular ablation (Pu1-/-), as well as functional impairment $\left(\mathrm{C} \times 3 \mathrm{Cr}^{-/-}\right)$ of microglia promote dopaminergic axonal outgrowth in the striatum. (C) Conversely, microglia functional alteration by maternal immune activation
(MIA) leads to reduced dopaminergic axonal outgrowth. (D) At E18.5, microglia localize in the deeper layers of the cortical plate, with Ihx6-expressing interneurons (gray dots) being concentrated in layer $\mathrm{V}$. (E,F) In absence of microglia (pharmacological depletion or Pu1-/-) pharmacological immune activation (MIA) or genetic functional alteration of microglia (Dap12-/-; Cx3cr1-/-), Ihx6-expressing interneurons prematurely entered the cortical plate, followed by an altered laminar distribution. DA, dopaminergic axons; INs, interneurons; IZ, intermediate zone; LGE, lateral ganglionic eminence; MGE, medial ganglionic eminence; Ncx, neocortex; UL, upper layers. depletion; $\mathrm{Pu} \cdot 1^{-/-}$), or in case of pharmacological (MIA) or genetic functional alteration (Dap $\left.12^{-/-} ; \mathrm{C} \times 3 \mathrm{crl}^{-/-}\right)$, a premature entry of lhx6-expressing interneurons in the CP was observed, followed by an altered laminar distribution, with long lasting postnatal effects on a subset of lhx6expressing interneurons, the fast-spiking parvalbumin-positive interneurons (Squarzoni et al., 2014). These specific interneurons have been shown to play a major role in cortical networks as well as to be impaired in ASD and Schizophrenia (Penagarikano et al., 2011; Marin, 2012; Meechan et al., 2012). While these results reveal a surprising role of microglia in cortical circuits assembly, as well as a potential involvement in the etiology of neuropsychiatric diseases, they raise the question of the underlying mechanisms. Besides the requirement of Dap12 and $\mathrm{Cx} 3 \mathrm{cr} 1$ signaling, the processes involved deserve further investigation.
These results reveal that microglia modulate brain wiring at various developmental steps, starting from embryonic, post-natal and adult stages. Moreover, they underlie the importance of spatial and temporal positioning of these cells to accomplish their roles as modulators of dopaminergic axonal outgrowth, CC development and neocortical interneuron laminar distribution, which are major events in forebrain wiring.

\section{Conclusions and Perspectives}

While the concept of guidepost cell has substantially changed since its first description, including a potential motility as well as a diverse cellular identity (neuronal or glial), there are still some conserved properties: they are usually early born, immature, located at a crucial point along a pathway and able to act at 
short-range or by direct cell-cell contact on its target. Along these lines, recent studies have revealed that microglia cells may be to some extent, envisaged as novel guideposts during embryonic forebrain wiring. By their transient specific localization during embryogenesis they may act on restricted neuronal subgroups and modulate forebrain wiring. If a comprehensive knowledge of all microglia functions is still fragmentary, the tremendous potential of these cells in shaping and remodeling circuits, during normal and pathological conditions, opens a novel framework for our understanding of brain wiring.

\section{References}

Adams, N. C., and Baker, G. E. (1995). Cells of the perireticular nucleus project to the developing neocortex of the rat. J. Comp. Neurol. 359, 613-626. doi: 10.1002/cne.903590408

Arno, B., Grassivaro, F., Rossi, C., Bergamaschi, A., Castiglioni, V., Furlan, R., et al. (2014). Neural progenitor cells orchestrate microglia migration and positioning into the developing cortex. Nat. Commun. 5:5611. doi: 10.1038/ncomms6611

Arnoux, I., Hoshiko, M., Mandavy, L., Avignone, E., Yamamoto, N., and Audinat, E. (2013). Adaptive phenotype of microglial cells during the normal postnatal development of the somatosensory "Barrel" cortex. Glia 61, 1582-1594. doi: 10.1002/glia.22503

Ashwell, K. (1991). The distribution of microglia and cell death in the fetal rat forebrain. Brain Res. Dev. Brain Res. 58, 1-12. doi: 10.1016/01653806(91)90231-7

Bagri, A., Marin, O., Plump, A. S., Mak, J., Pleasure, S. J., Rubenstein, J. L., et al. (2002). Slit proteins prevent midline crossing and determine the dorsoventral position of major axonal pathways in the mammalian forebrain. Neuron 33, 233-248. doi: 10.1016/S0896-6273(02)00561-5

Barresi, M. J., Hutson, L. D., Chien, C. B., and Karlstrom, R. O. (2005). Hedgehog regulated Slit expression determines commissure and glial cell position in the zebrafish forebrain. Development 132, 3643-3656. doi: 10.1242/dev.01929

Batista-Brito, R., and Fishell, G. (2009). The developmental integration of cortical interneurons into a functional network. Curr. Top. Dev. Biol. 87, 81-118. doi: 10.1016/S0070-2153(09)01203-4

Bayer, S. A., and Altman, J. (1987). Directions in neurogenetic gradients and patterns of anatomical connections in the telencephalon. Prog. Neurobiol. 29, 57-106. doi: 10.1016/0301-0082(87)90015-3

Bentley, D., and Caudy, M. (1983). Pioneer axons lose directed growth after selective killing of guidepost cells. Nature 304, 62-65. doi: 10.1038/30 $4062 \mathrm{a} 0$

Bielle, F., Griveau, A., Narboux-Neme, N., Vigneau, S., Sigrist, M., Arber, S., et al. (2005). Multiple origins of Cajal-Retzius cells at the borders of the developing pallium. Nat. Neurosci. 8, 1002-1012. doi: 10.1038/nn1511

Bielle, F., Marcos-Mondejar, P., Keita, M., Mailhes, C., Verney, C., Nguyen BaCharvet, K., et al. (2011). Slit2 activity in the migration of guidepost neurons shapes thalamic projections during development and evolution. Neuron 69, 1085-1098. doi: 10.1016/j.neuron.2011.02.026

Bilimoria, P. M., and Stevens, B. (2014). Microglia function during brain development: New insights from animal models. Brain Res. 1617, 7-17. doi: 10.1016/j.brainres.2014.11.032

Bishop, K. M., Garel, S., Nakagawa, Y., Rubenstein, J. L., and O’leary, D. D. (2003). Emx1 and Emx2 cooperate to regulate cortical size, lamination, neuronal differentiation, development of cortical efferents, and thalamocortical pathfinding. J. Comp. Neurol. 457, 345-360. doi: 10.1002/cne.10550

Bishop, K. M., Goudreau, G., and O'leary, D. D. (2000). Regulation of area identity in the mammalian neocortex by Emx2 and Pax6. Science 288, 344-349. doi: $10.1126 /$ science.288.5464.344

Blakemore, C., and Molnar, Z. (1990). Factors involved in the establishment of specific interconnections between thalamus and cerebral cortex. Cold Spring Harb. Symp. Quant. Biol. 55, 491-504. doi: 10.1101/SQB.1990.055.01.048

\section{Acknowledgments}

We are grateful to members of the Garel lab for stimulating inputs, discussions and critical comments on the manuscript. The lab is supported by Investissements d'Avenir implemented by ANR-10-LABX-54 MEMO LIFE, ANR-11-IDEX-0001-02 PSL* Research University, the ANR-12-BVS4-0010-01 Corridor and ERC Consolidator NImO. SG is an EMBO YIP awardee and part of the Ecole des Neurosciences de Paris Ile-de-France network.

Bonnin, A., Torii, M., Wang, L., Rakic, P., and Levitt, P. (2007). Serotonin modulates the response of embryonic thalamocortical axons to netrin-1. Nat. Neurosci. 10, 588-597. doi: 10.1038/nn1896

Borello, U., and Pierani, A. (2010). Patterning the cerebral cortex: traveling with morphogens. Curr. Opin. Genet. Dev. 20, 408-415. doi: 10.1016/j.gde.2010.05.003

Borrell, V., Del Rio, J. A., Alcantara, S., Derer, M., Martinez, A., D’arcangelo, G., et al. (1999). Reelin regulates the development and synaptogenesis of the layer-specific entorhino-hippocampal connections. J. Neurosci. 19, 1345-1358.

Borrell, V., and Marin, O. (2006). Meninges control tangential migration of hemderived Cajal-Retzius cells via CXCL12/CXCR4 signaling. Nat. Neurosci. 9, 1284-1293. doi: 10.1038/nn1764

Bovolenta, P., and Dodd, J. (1990). Guidance of commissural growth cones at the floor plate in embryonic rat spinal cord. Development 109, 435-447.

Bovolenta, P., and Dodd, J. (1991). Perturbation of neuronal differentiation and axon guidance in the spinal cord of mouse embryos lacking a floor plate: analysis of Danforth's short-tail mutation. Development 113, 625-639.

Braisted, J. E., Catalano, S. M., Stimac, R., Kennedy, T. E., Tessier-Lavigne, M., Shatz, C. J., et al. (2000). Netrin-1 promotes thalamic axon growth and is required for proper development of the thalamocortical projection. J. Neurosci. 20, 5792-5801.

Braisted, J. E., Ringstedt, T., and O'leary, D. D. (2009). Slits are chemorepellents endogenous to hypothalamus and steer thalamocortical axons into ventral telencephalon. Cereb. Cortex 19 (Suppl. 1), i144-i151. doi: 10.1093/cercor/bhp035

Braisted, J. E., Tuttle, R., and O'leary, D., D. (1999). Thalamocortical axons are influenced by chemorepellent and chemoattractant activities localized to decision points along their path. Dev. Biol. 208, 430-440. doi: 10.1006/dbio.1999.9216

Bribian, A., Nocentini, S., Llorens, F., Gil, V., Mire, E., Reginensi, D., et al. (2014). Sema3E/PlexinD1 regulates the migration of hem-derived Cajal-Retzius cells in developing cerebral cortex. Nat. Commun. 5, 4265. doi: 10.1038/ncomms5265

Cabrera-Socorro, A., Hernandez-Acosta, N. C., Gonzalez-Gomez, M., and Meyer, G. (2007). Comparative aspects of p73 and Reelin expression in Cajal-Retzius cells and the cortical hem in lizard, mouse and human. Brain Res. 1132, 59-70. doi: 10.1016/j.brainres.2006.11.015

Campbell, R. M., and Peterson, A. C. (1993). Expression of a lacZ transgene reveals floor plate cell morphology and macromolecular transfer to commissural axons. Development 119, 1217-1228.

Casano, A. M., and Peri, F. (2015). Microglia: multitasking specialists of the brain. Dev. Cell 32, 469-477. doi: 10.1016/j.devcel.2015.01.018

Caviness, V. S. Jr. (1973). Time of neuron origin in the hippocampus and dentate gyrus of normal and reeler mutant mice: an autoradiographic analysis. J. Comp. Neurol. 151, 113-120. doi: 10.1002/cne.901510203

Ceci, M. L., Lopez-Mascaraque, L., and De Carlos, J. A. (2010). The influence of the environment on Cajal-Retzius cell migration. Cereb. Cortex 20, 2348-2360. doi: 10.1093/cercor/bhp305

Chen, H., Bagri, A., Zupicich, J. A., Zou, Y., Stoeckli, E., Pleasure, S. J., et al. (2000). Neuropilin-2 regulates the development of selective cranial and sensory nerves and hippocampal mossy fiber projections. Neuron 25, 43-56. doi: 10.1016/S0896-6273(00)80870-3 
Chen, Y. J., Magnani, D., Theil, T., Pratt, T., and Price, D. J. (2012). Evidence that descending cortical axons are essential for thalamocortical axons to cross the pallial-subpallial boundary in the embryonic forebrain. PLOS ONE 7:e33105. doi: 10.1371/journal.pone.0033105

Cossart, R. (2011). The maturation of cortical interneuron diversity: how multiple developmental journeys shape the emergence of proper network function. Curr. Opin. Neurobiol. 21, 160-168. doi: 10.1016/j.conb.2010.10.003

Cuadros, M. A., and Navascues, J. (2001). Early origin and colonization of the developing central nervous system by microglial precursors. Prog. Brain Res. 132, 51-59. doi: 10.1016/S0079-6123(01)32065-4

Cunningham, C. L., Martinez-Cerdeno, V., and Noctor, S. C. (2013). Microglia regulate the number of neural precursor cells in the developing cerebral cortex. J. Neurosci. 33, 4216-4233. doi: 10.1523/JNEUROSCI.3441-12.2013

D'arcangelo, G., Miao, G. G., Chen, S. C., Soares, H. D., Morgan, J. I., and Curran, T. (1995). A protein related to extracellular matrix proteins deleted in the mouse mutant reeler. Nature 374, 719-723. doi: 10.1038/374719a0

D’arcangelo, G., Nakajima, K., Miyata, T., Ogawa, M., Mikoshiba, K., and Curran, T. (1997). Reelin is a secreted glycoprotein recognized by the CR-50 monoclonal antibody. J. Neurosci. 17, 23-31.

Davalos, D., Grutzendler, J., Yang, G., Kim, J. V., Zuo, Y., Jung, S., et al. (2005). ATP mediates rapid microglial response to local brain injury in vivo. Nat. Neurosci. 8, 752-758. doi: $10.1038 / \mathrm{nn} 1472$

De Castro, F. (2009). Wiring olfaction: the cellular and molecular mechanisms that guide the development of synaptic connections from the nose to the cortex. Front. Neurosci. 3, 52. doi: 10.3389/neuro.22.004.2009

De Castro, F., Hu, L., Drabkin, H., Sotelo, C., and Chedotal, A. (1999). Chemoattraction and chemorepulsion of olfactory bulb axons by different secreted semaphorins. J. Neurosci. 19, 4428-4436.

Deck, M., Lokmane, L., Chauvet, S., Mailhes, C., Keita, M., Niquille, M., et al. (2013). Pathfinding of corticothalamic axons relies on a rendezvous with thalamic projections. Neuron 77, 472-484. doi: 10.1016/j.neuron.2012.11.031

Deller, T., Drakew, A., Heimrich, B., Forster, E., Tielsch, A., and Frotscher, M. (1999). The hippocampus of the reeler mutant mouse: fiber segregation in area CA1 depends on the position of the postsynaptic target cells. Exp. Neurol. 156, 254-267. doi: 10.1006/exnr.1999.7021

Del Rio-Hortega, P. (1932). Microglia. New York, NY: P. B. Hoeber.

Del Rio, J. A., Heimrich, B., Borrell, V., Forster, E., Drakew, A., Alcantara, S., et al. (1997). A role for Cajal-Retzius cells and reelin in the development of hippocampal connections. Nature 385, 70-74. doi: 10.1038/385070a0

Demyanenko, G. P., Riday, T. T., Tran, T. S., Dalal, J., Darnell, E. P., Brennaman, L. H., et al. (2011a). NrCAM deletion causes topographic mistargeting of thalamocortical axons to the visual cortex and disrupts visual acuity. J. Neurosci. 31, 1545-1558. doi: 10.1523/JNEUROSCI.4467-10.2011

Demyanenko, G. P., Siesser, P. F., Wright, A. G., Brennaman, L. H., Bartsch, U., Schachner, M., et al. (2011b). L1 and CHL1 cooperate in thalamocortical axon targeting. Cereb. Cortex 21, 401-412. doi: 10.1093/cercor/bhq115

Deng, J. B., Yu, D. M., and Li, M. S. (2006). Formation of the entorhinohippocampal pathway: a tracing study in vitro and in vivo. Neurosci. Bull. 22, 305-314.

Deng, J., and Elberger, A. J. (2001). The role of pioneer neurons in the development of mouse visual cortex and corpus callosum. Anat Embryol (Berl). 204, 437-453. doi: 10.1007/s429-001-8001-3

Derer, P., Caviness, V. S. Jr., and Sidman, R. L. (1977). Early cortical histogenesis in the primary olfactory cortex of the mouse. Brain Res. 123, 27-40. doi: 10.1016/0006-8993(77)90641-2

Dixit, R., Wilkinson, G., Cancino, G. I., Shaker, T., Adnani, L., Li, S., et al. (2014). Neurog1 and Neurog 2 control two waves of neuronal differentiation in the piriform cortex. J. Neurosci. 34, 539-553. doi: 10.1523/JNEUROSCI.061413.2014

Duffield, J. S., Forbes, S. J., Constandinou, C. M., Clay, S., Partolina, M., Vuthoori, S., et al. (2005). Selective depletion of macrophages reveals distinct, opposing roles during liver injury and repair. J. Clin. Invest. 115, 56-65. doi: 10.1172/JCI200522675

Dufour, A., Seibt, J., Passante, L., Depaepe, V., Ciossek, T., Frisen, J., et al. (2003). Area specificity and topography of thalamocortical projections are controlled by ephrin/Eph genes. Neuron 39, 453-465. doi: 10.1016/S0896-6273(03) 00440-9
Elmore, M. R., Najafi, A. R., Koike, M. A., Dagher, N. N., Spangenberg, E. E., Rice, R. A., et al. (2014). Colony-stimulating factor 1 receptor signaling is necessary for microglia viability, unmasking a microglia progenitor cell in the adult brain. Neuron 82, 380-397. doi: 10.1016/j.neuron.2014. 02.040

Erblich, B., Zhu, L., Etgen, A. M., Dobrenis, K., and Pollard, J. W. (2011). Absence of colony stimulation factor-1 receptor results in loss of microglia, disrupted brain development and olfactory deficits. PLoS ONE 6:e26317. doi: 10.1371/journal.pone.0026317

Erskine, L., Williams, S. E., Brose, K., Kidd, T., Rachel, R. A., Goodman, C. S., et al. (2000). Retinal ganglion cell axon guidance in the mouse optic chiasm: expression and function of robos and slits. J. Neurosci. 20, 4975-4982.

Fishell, G., and Rudy, B. (2011). Mechanisms of inhibition within the telencephalon: "where the wild things are". Annu. Rev. Neurosci. 34, 535-567. doi: 10.1146/annurev-neuro-061010-113717

Forster, E., Kaltschmidt, C., Deng, J., Cremer, H., Deller, T., and Frotscher, M. (1998). Lamina-specific cell adhesion on living slices of hippocampus. Development 125, 3399-3410.

Fouquet, C., Di Meglio, T., Ma, L., Kawasaki, T., Long, H., Hirata, T., et al. (2007). Robo1 and robo2 control the development of the lateral olfactory tract. J. Neurosci. 27, 3037-3045. doi: 10.1523/JNEUROSCI.0172-07.2007

Fraher, J. P., Dockery, P., O'donoghue, O., Riedewald, B., and O'leary, D. (2007). Initial motor axon outgrowth from the developing central nervous system. J. Anat. 211, 600-611. doi: 10.1111/j.1469-7580.2007.00807.x

Frotscher, M. (2010). Role for Reelin in stabilizing cortical architecture. Trends Neurosci. 33, 407-414. doi: 10.1016/j.tins.2010.06.001

Frotscher, M., and Heimrich, B. (1993). Formation of layer-specific fiber projections to the hippocampus in vitro. Proc. Natl. Acad. Sci. U.S.A. 90, 10400-10403. doi: 10.1073/pnas.90.21.10400

Frotscher, M., Zafirov, S., and Heimrich, B. (1995). Development of identified neuronal types and of specific synaptic connections in slice cultures of rat hippocampus. Prog. Neurobiol. 45, 143-164. doi: 10.1016/0301-0082(94) 00040-O

Garel, S., and Lopez-Bendito, G. (2014). Inputs from the thalamocortical system on axon pathfinding mechanisms. Curr. Opin. Neurobiol. 27, 143-150. doi: 10.1016/j.conb.2014.03.013

Garel, S., Marin, F., Grosschedl, R., and Charnay, P. (1999). Ebf1 controls early cell differentiation in the embryonic striatum. Development 126, 5285-5294.

Ghosh, A., Antonini, A., Mcconnell, S. K., and Shatz, C. J. (1990). Requirement for subplate neurons in the formation of thalamocortical connections. Nature 347, 179-181. doi: $10.1038 / 347179 \mathrm{a} 0$

Ghosh, A., and Shatz, C. J. (1993). A role for subplate neurons in the patterning of connections from thalamus to neocortex. Development 117, 1031-1047.

Gil-Sanz, C., Franco, S. J., Martinez-Garay, I., Espinosa, A., Harkins-Perry, S., and Muller, U. (2013). Cajal-Retzius cells instruct neuronal migration by coincidence signaling between secreted and contact-dependent guidance cues. Neuron 79, 461-477. doi: 10.1016/j.neuron.2013.06.040

Ginhoux, F., Greter, M., Leboeuf, M., Nandi, S., See, P., Gokhan, S., et al. (2010). Fate mapping analysis reveals that adult microglia derive from primitive macrophages. Science 330, 841-845. doi: 10.1126/science.1194637

Ginhoux, F., Lim, S., Hoeffel, G., Low, D., and Huber, T. (2013). Origin and differentiation of microglia. Front. Cell. Neurosci. 7:45. doi: 10.3389/fncel.2013.00045

Golding, J. P., and Cohen, J. (1997). Border controls at the mammalian spinal cord: late-surviving neural crest boundary cap cells at dorsal root entry sites may regulate sensory afferent ingrowth and entry zone morphogenesis. Mol. Cell. Neurosci. 9, 381-396. doi: 10.1006/mcne.1997.0647

Gomez Perdiguero, E., Schulz, C., and Geissmann, F. (2013). Development and homeostasis of "resident" myeloid cells: the case of the microglia. Glia 61 , 112-120. doi: 10.1002/glia.22393

Griveau, A., Borello, U., Causeret, F., Tissir, F., Boggetto, N., Karaz, S., et al. (2010). A novel role for Dbx1-derived Cajal-Retzius cells in early regionalization of the cerebral cortical neuroepithelium. PLoS Biol. 8:e1000440. doi: 10.1371/journal.pbio.1000440

Grove, E. A., Tole, S., Limon, J., Yip, L., and Ragsdale, C. W. (1998). The hem of the embryonic cerebral cortex is defined by the expression of multiple Wnt genes and is compromised in Gli3-deficient mice. Development 125, 2315-2325. 
Gu, X., Liu, B., Wu, X., Yan, Y., Zhang, Y., Wei, Y., et al. (2011). Inducible genetic lineage tracing of cortical hem derived Cajal-Retzius cells reveals novel properties. PLoS ONE 6:e28653. doi: 10.1371/journal.pone.0028653

Guillery, R. W., Mason, C. A., and Taylor, J. S. (1995). Developmental determinants at the mammalian optic chiasm. J. Neurosci. 15, 4727-4737.

Heppner, F. L., Greter, M., Marino, D., Falsig, J., Raivich, G., Hovelmeyer, N., et al. (2005). Experimental autoimmune encephalomyelitis repressed by microglial paralysis. Nat. Med. 11, 146-152. doi: 10.1038/nm1177

Herbomel, P., Thisse, B., and Thisse, C. (2001). Zebrafish early macrophages colonize cephalic mesenchyme and developing brain, retina, and epidermis through a M-CSF receptor-dependent invasive process. Dev. Biol. 238, 274-288. doi: 10.1006/dbio.2001.0393

Hevner, R. F., Neogi, T., Englund, C., Daza, R. A., and Fink, A. (2003). CajalRetzius cells in the mouse: transcription factors, neurotransmitters, and birthdays suggest a pallial origin. Brain Res. Dev. Brain Res. 141, 39-53. doi: 10.1016/S0165-3806(02)00641-7

Hirata, T., and Fujisawa, H. (1999). Environmental control of collateral branching and target invasion of mitral cell axons during development. J. Neurobiol. 38, 93-104.

Hirata, T., Kumada, T., Kawasaki, T., Furukawa, T., Aiba, A., Conquet, F., et al. (2012). Guidepost neurons for the lateral olfactory tract: expression of metabotropic glutamate receptor 1 and innervation by glutamatergic olfactory bulb axons. Dev. Neurobiol. 72, 1559-1576. doi: 10.1002/dneu.22030

Hirotsune, S., Takahara, T., Sasaki, N., Hirose, K., Yoshiki, A., Ohashi, T., et al. (1995). The reeler gene encodes a protein with an EGF-like motif expressed by pioneer neurons. Nat. Genet. 10, 77-83. doi: 10.1038/ng0595-77

Hoeffel, G., Chen, J., Lavin, Y., Low, D., Almeida, F. F., See, P., et al. (2015). C-myb(+) erythro-myeloid progenitor-derived fetal monocytes give rise to adult tissue-resident macrophages. Immunity 42, 665-678. doi: 10.1016/j.immuni.2015.03.011

Hoerder-Suabedissen, A., and Molnar, Z. (2015). Development, evolution and pathology of neocortical subplate neurons. Nat. Rev. Neurosci. 16, 133-146. doi: $10.1038 / \mathrm{nrn} 3915$

Hoshiko, M., Arnoux, I., Avignone, E., Yamamoto, N., and Audinat, E. (2012). Deficiency of the microglial receptor CX3CR1 impairs postnatal functional development of thalamocortical synapses in the barrel cortex. J. Neurosci. 32, 15106-15111. doi: 10.1523/JNEUROSCI.1167-12.2012

Islam, S. M., Shinmyo, Y., Okafuji, T., Su, Y., Naser, I. B., Ahmed, G., et al. (2009). Draxin, a repulsive guidance protein for spinal cord and forebrain commissures. Science 323, 388-393. doi: 10.1126/science.1165187

Ito, K., Kawasaki, T., Takashima, S., Matsuda, I., Aiba, A., and Hirata, T. (2008). Semaphorin $3 \mathrm{~F}$ confines ventral tangential migration of lateral olfactory tract neurons onto the telencephalon surface. J. Neurosci. 28, 4414-4422. doi: 10.1523/JNEUROSCI.0372-08.2008

Katsumoto, A., Lu, H., Miranda, A. S., and Ransohoff, R. M. (2014). Ontogeny and functions of central nervous system macrophages. J. Immunol. 193, 2615-2621. doi: 10.4049/jimmunol.1400716

Kawasaki, T., Ito, K., and Hirata, T. (2006). Netrin 1 regulates ventral tangential migration of guidepost neurons in the lateral olfactory tract. Development 133, 845-853. doi: $10.1242 /$ dev.02257

Keeble, T. R., and Cooper, H. M. (2006). Ryk: a novel Wnt receptor regulating axon pathfinding. Int. J. Biochem. Cell Biol. 38, 2011-2017. doi: 10.1016/j.biocel.2006.07.005

Kennedy, T. E., Serafini, T., De La Torre, J. R., and Tessier-Lavigne, M. (1994). Netrins are diffusible chemotropic factors for commissural axons in the embryonic spinal cord. Cell 78, 425-435. doi: 10.1016/0092-8674(94) 90421-9

Kettenmann, H., Kirchhoff, F., and Verkhratsky, A. (2013). Microglia: new roles for the synaptic stripper. Neuron 77, 10-18. doi: 10.1016/j.neuron.2012.12.023

Kierdorf, K., Erny, D., Goldmann, T., Sander, V., Schulz, C., Perdiguero, E. G., et al. (2013). Microglia emerge from erythromyeloid precursors via Pu.1- and Irf8-dependent pathways. Nat. Neurosci. 16, 273-280. doi: 10.1038/nn.3318

Kuhn, T. B., Schmidt, M. F., and Kater, S. B. (1995). Laminin and fibronectin guideposts signal sustained but opposite effects to passing growth cones. Neuron 14, 275-285. doi: 10.1016/0896-6273(95)90285-6

Kwon, H. J., Ma, S., and Huang, Z. (2011). Radial glia regulate Cajal-Retzius cell positioning in the early embryonic cerebral cortex. Dev. Biol. 351, 25-34. doi: 10.1016/j.ydbio.2010.12.026
Lakhina, V., Falnikar, A., Bhatnagar, L., and Tole, S. (2007). Early thalamocortical tract guidance and topographic sorting of thalamic projections requires LIM-homeodomain gene Lhx2. Dev. Biol. 306, 703-713. doi: 10.1016/j.ydbio.2007.04.007

Leighton, P. A., Mitchell, K. J., Goodrich, L. V., Lu, X., Pinson, K., Scherz, P., et al. (2001). Defining brain wiring patterns and mechanisms through gene trapping in mice. Nature 410, 174-179. doi: 10.1038/35065539

Lent, R., Uziel, D., Baudrimont, M., and Fallet, C. (2005). Cellular and molecular tunnels surrounding the forebrain commissures of human fetuses. J. Comp. Neurol. 483, 375-382. doi: 10.1002/cne.20427

Li, D., Field, P. M., Starega, U., Li, Y., and Raisman, G. (1993). Entorhinal axons project to dentate gyrus in organotypic slice co-culture. Neuroscience 52 , 799-813. doi: 10.1016/0306-4522(93)90530-S

Li, Y., Du, X. F., Liu, C. S., Wen, Z. L., and Du, J. L. (2012). Reciprocal regulation between resting microglial dynamics and neuronal activity in vivo. Dev. Cell 23, 1189-1202. doi: 10.1016/j.devcel.2012.10.027

Little, G. E., Lopez-Bendito, G., Runker, A. E., Garcia, N., Pinon, M. C., Chedotal, A., et al. (2009). Specificity and plasticity of thalamocortical connections in Sema6A mutant mice. PLoS Biol. 7:e98. doi: 10.1371/journal.pbio.1000098

Lokmane, L., and Garel, S. (2014). Map transfer from the thalamus to the neocortex: inputs from the barrel field. Semin. Cell Dev. Biol. 35, 147-155. doi: 10.1016/j.semcdb.2014.07.005

Lokmane, L., Proville, R., Narboux-Neme, N., Gyory, I., Keita, M., Mailhes, C., et al. (2013). Sensory map transfer to the neocortex relies on pretarget ordering of thalamic axons. Curr. Biol. 23, 810-816. doi: 10.1016/j.cub.2013.03.062

Lopez-Bendito, G., Cautinat, A., Sanchez, J. A., Bielle, F., Flames, N., Garratt, A. N., et al. (2006). Tangential neuronal migration controls axon guidance: a role for neuregulin-1 in thalamocortical axon navigation. Cell 125, 127-142. doi: 10.1016/j.cell.2006.01.042

Lopez-Bendito, G., Chan, C. H., Mallamaci, A., Parnavelas, J., and Molnar, Z. (2002). Role of Emx2 in the development of the reciprocal connectivity between cortex and thalamus. J. Comp. Neurol. 451, 153-169. doi: 10.1002/cne.10345

Lopez-Bendito, G., Flames, N., Ma, L., Fouquet, C., Di Meglio, T., Chedotal, A., et al. (2007). Robol and Robo2 cooperate to control the guidance of major axonal tracts in the mammalian forebrain. J. Neurosci. 27, 3395-3407. doi: 10.1523/JNEUROSCI.4605-06.2007

Mandai, K., Reimert, D. V., and Ginty, D. D. (2014). Linx mediates interaxonal interactions and formation of the internal capsule. Neuron 83, 93-103. doi: 10.1016/j.neuron.2014.05.020

Marcus, R. C., Blazeski, R., Godement, P., and Mason, C. A. (1995). Retinal axon divergence in the optic chiasm: uncrossed axons diverge from crossed axons within a midline glial specialization. J. Neurosci. 15, 3716-3729.

Marcus, R. C., and Mason, C. A. (1995). The first retinal axon growth in the mouse optic chiasm: axon patterning and the cellular environment. J. Neurosci. 15, 6389-6402.

Marin, O. (2012). Interneuron dysfunction in psychiatric disorders. Nat. Rev. Neurosci. 13, 107-120. doi: 10.1038/nrn3155

Marin, O., Baker, J., Puelles, L., and Rubenstein, J. L. (2002). Patterning of the basal telencephalon and hypothalamus is essential for guidance of cortical projections. Development 129, 761-773.

Marin, O., and Muller, U. (2014). Lineage origins of GABAergic versus glutamatergic neurons in the neocortex. Curr. Opin. Neurobiol. 26, 132-141. doi: $10.1016 /$ j.conb.2014.01.015

Marin, O., and Rubenstein, J. L. (2003). Cell migration in the forebrain. Annu. Rev. Neurosci. 26, 441-483. doi: 10.1146/annurev.neuro.26.041002.131058

Marin, O., and Rubenstein, J. L. R. (2002). "Patterning, regionalization and cell differentiation in the forebrain," in Mouse Development, eds J. Rossant and P. Tam (London: Academic Press), 75-106.

Marin-Teva, J. L., Dusart, I., Colin, C., Gervais, A., Van Rooijen, N., and Mallat, M. (2004). Microglia promote the death of developing Purkinje cells. Neuron 41, 535-547. doi: 10.1016/S0896-6273(04)00069-8

Martinez-Cerdeno, V., and Noctor, S. C. (2014). Cajal, Retzius, and Cajal-Retzius cells. Front. Neuroanat. 8:48. doi: 10.3389/fnana.2014.00048

Meechan, D. W., Tucker, E. S., Maynard, T. M., and Lamantia, A. S. (2012). Cxcr4 regulation of interneuron migration is disrupted in 22q11.2 deletion syndrome. Proc. Natl. Acad. Sci. U.S.A. 109, 18601-18606. doi: 10.1073/pnas.1211507109

Mendes, S. W., Henkemeyer, M., and Liebl, D. J. (2006). Multiple Eph receptors and B-class ephrins regulate midline crossing of corpus callosum 
fibers in the developing mouse forebrain. J. Neurosci. 26, 882-892. doi: 10.1523/JNEUROSCI.3162-05.2006

Metin, C., and Godement, P. (1996). The ganglionic eminence may be an intermediate target for corticofugal and thalamocortical axons. J. Neurosci. 16, 3219-3235.

Meyer, G. (2010). Building a human cortex: the evolutionary differentiation of Cajal-Retzius cells and the cortical hem. J. Anat. 217, 334-343. doi: 10.1111/j.1469-7580.2010.01266.x

Meyer, G., Goffinet, A. M., and Fairen, A. (1999). What is a Cajal-Retzius cell? A reassessment of a classical cell type based on recent observations in the developing neocortex. Cereb. Cortex 9, 765-775. doi: 10.1093/cercor/9. 8.765

Meyer, G., Perez-Garcia, C. G., Abraham, H., and Caput, D. (2002). Expression of p73 and Reelin in the developing human cortex. J. Neurosci. 22, 4973-4986.

Meyer, G., and Wahle, P. (1999). The paleocortical ventricle is the origin of reelinexpressing neurons in the marginal zone of the foetal human neocortex. Eur. J. Neurosci. 11, 3937-3944. doi: 10.1046/j.1460-9568.1999.00818.x

Mildner, A., Schmidt, H., Nitsche, M., Merkler, D., Hanisch, U. K., Mack, M., et al. (2007). Microglia in the adult brain arise from Ly-6ChiCCR2+ monocytes only under defined host conditions. Nat. Neurosci. 10, 1544-1553. doi: $10.1038 / \mathrm{nn} 2015$

Misson, J. P., Edwards, M. A., Yamamoto, M., and Caviness, V. S. Jr. (1988). Identification of radial glial cells within the developing murine central nervous system: studies based upon a new immunohistochemical marker. Brain Res. Dev. Brain Res. 44, 95-108. doi: 10.1016/0165-3806(88)90121-6

Mitrofanis, J. (1992). Patterns of antigenic expression in the thalamic reticular nucleus of developing rats. J. Comp. Neurol. 320, 161-181. doi: 10.1002/cne. 903200203

Mitrofanis, J. (1994). Development of the thalamic reticular nucleus in ferrets with special reference to the perigeniculate and perireticular cell groups. Eur. J. Neurosci. 6, 253-263. doi: 10.1111/j.1460-9568.1994.tb00268.x

Mitrofanis, J., and Baker, G. E. (1993). Development of the thalamic reticular and perireticular nuclei in rats and their relationship to the course of growing corticofugal and corticopetal axons. J. Comp. Neurol. 338, 575-587. doi: $10.1002 /$ cne. 903380407

Mitrofanis, J., and Guillery, R. W. (1993). New views of the thalamic reticular nucleus in the adult and the developing brain. Trends Neurosci. 16, 240-245. doi: 10.1016/0166-2236(93)90163-G

Molnar, Z., Adams, R., and Blakemore, C. (1998a). Mechanisms underlying the early establishment of thalamocortical connections in the rat. J. Neurosci. 18, 5723-5745.

Molnar, Z., Adams, R., Goffinet, A. M., and Blakemore, C. (1998b). The role of the first postmitotic cortical cells in the development of thalamocortical innervation in the reeler mouse. J. Neurosci. 18, 5746-5765.

Molnar, Z., and Blakemore, C. (1991). Lack of regional specificity for connections formed between thalamus and cortex in coculture. Nature 351, 475-477. doi: $10.1038 / 351475 \mathrm{a} 0$

Molnar, Z., and Blakemore, C. (1995). How do thalamic axons find their way to the cortex? Trends Neurosci. 18, 389-397. doi: 10.1016/0166-2236(95)93935-Q

Molnar, Z., and Cordery, P. (1999). Connections between cells of the internal capsule, thalamus, and cerebral cortex in embryonic rat. J. Comp. Neurol. 413, $1-25$.

Molnar, Z., Garel, S., Lopez-Bendito, G., Maness, P., and Price, D. J. (2012). Mechanisms controlling the guidance of thalamocortical axons through the embryonic forebrain. Eur. J. Neurosci. 35, 1573-1585. doi: 10.1111/j.14609568.2012.08119.x

Nguyen Ba-Charvet, K. T., Brose, K., Marillat, V., Kidd, T., Goodman, C. S., Tessier-Lavigne, M., et al. (1999). Slit2-Mediated chemorepulsion and collapse of developing forebrain axons. Neuron 22, 463-473. doi: 10.1016/S08966273(00)80702-3

Nguyen-Ba-Charvet, K. T., Plump, A. S., Tessier-Lavigne, M., and Chedotal, A. (2002). Slit1 and slit2 proteins control the development of the lateral olfactory tract. J. Neurosci. 22, 5473-5480.

Nimmerjahn, A., Kirchhoff, F., and Helmchen, F. (2005). Resting microglial cells are highly dynamic surveillants of brain parenchyma in vivo. Science 308, 1314-1318. doi: 10.1126/science.1110647

Niquille, M., Garel, S., Mann, F., Hornung, J. P., Otsmane, B., Chevalley, S., et al. (2009). Transient neuronal populations are required to guide callosal axons: a role for semaphorin 3C. PLoS Biol. 7:e1000230. doi: 10.1371/journal.pbio. 1000230

Nomura, T., Holmberg, J., Frisen, J., and Osumi, N. (2006). Pax6-dependent boundary defines alignment of migrating olfactory cortex neurons via the repulsive activity of ephrin A5. Development 133, 1335-1345. doi: 10.1242/dev.02290

Ogawa, M., Miyata, T., Nakajima, K., Yagyu, K., Seike, M., Ikenaka, K., et al. (1995). The reeler gene-associated antigen on Cajal-Retzius neurons is a crucial molecule for laminar organization of cortical neurons. Neuron 14, 899-912. doi: 10.1016/0896-6273(95)90329-1

Paolicelli, R. C., Bisht, K., and Tremblay, M. E. (2014). Fractalkine regulation of microglial physiology and consequences on the brain and behavior. Front. Cell. Neurosci. 8:129. doi: 10.3389/fncel.2014.00129

Paolicelli, R. C., Bolasco, G., Pagani, F., Maggi, L., Scianni, M., Panzanelli, P., et al. (2011). Synaptic pruning by microglia is necessary for normal brain development. Science 333, 1456-1458. doi: 10.1126/science.1202529

Paolicelli, R. C., and Gross, C. T. (2011). Microglia in development: linking brain wiring to brain environment. Neuron Glia Biol. 7, 77-83. doi: 10.1017/S1740925X12000105

Parkhurst, C. N., Yang, G., Ninan, I., Savas, J. N., Yates, J. R. III, Lafaille, J. J., et al. (2013). Microglia promote learning-dependent synapse formation through brain-derived neurotrophic factor. Cell 155, 1596-1609. doi: 10.1016/j.cell.2013.11.030

Pascual, O., Ben Achour, S., Rostaing, P., Triller, A., and Bessis, A. (2012). Microglia activation triggers astrocyte-mediated modulation of excitatory neurotransmission. Proc. Natl. Acad. Sci. U.S.A. 109, E197-E205. doi: 10.1073/pnas.1111098109

Penagarikano, O., Abrahams, B. S., Herman, E. I., Winden, K. D., Gdalyahu, A., Dong, H., et al. (2011). Absence of CNTNAP2 leads to epilepsy, neuronal migration abnormalities, and core autism-related deficits. Cell 147, 235-246. doi: 10.1016/j.cell.2011.08.040

Perry, V. H., Hume, D. A., and Gordon, S. (1985). Immunohistochemical localization of macrophages and microglia in the adult and developing mouse brain. Neuroscience 15, 313-326. doi: 10.1016/0306-4522(85) 90215-5

Pini, A. (1993). Chemorepulsion of axons in the developing mammalian central nervous system. Science 261, 95-98. doi: 10.1126/science.8316861

Pires-Neto, M. A., Braga-De-Souza, S., and Lent, R. (1998). Molecular tunnels and boundaries for growing axons in the anterior commissure of hamster embryos. J. Comp. Neurol. 399, 176-188.

Placzek, M., Tessier-Lavigne, M., Jessell, T., and Dodd, J. (1990). Orientation of commissural axons in vitro in response to a floor plate-derived chemoattractant. Development 110, 19-30.

Plump, A. S., Erskine, L., Sabatier, C., Brose, K., Epstein, C. J., Goodman, C. S., et al. (2002). Slit1 and Slit2 cooperate to prevent premature midline crossing of retinal axons in the mouse visual system. Neuron 33, 219-232. doi: 10.1016/S0896-6273(01)00586-4

Pont-Lezica, L., Beumer, W., Colasse, S., Drexhage, H., Versnel, M., and Bessis, A. (2014). Microglia shape corpus callosum axon tract fasciculation: functional impact of prenatal inflammation. Eur. J. Neurosci. 39, 1551-1557. doi: 10.1111/ejn. 12508

Powell, A. W., Sassa, T., Wu, Y., Tessier-Lavigne, M., and Polleux, F. (2008). Topography of thalamic projections requires attractive and repulsive functions of Netrin-1 in the ventral telencephalon. PLoS Biol. 6:e116. doi: 10.1371/journal.pbio.0060116

Qu, Y. B., Huang, Y. H., Feng, J., Alvarez-Bolado, G., Grove, E. A., Yang, Y. Z., et al. (2014). Genetic evidence that Celsr3 and Celsr2, together with Fzd3, regulate forebrain wiring in a Vangl-independent manner. Proc. Natl. Acad. Sci. U.S.A. 111, E2996-E3004. doi: 10.1073/pnas.1402105111

Rico, B., and Marin, O. (2011). Neuregulin signaling, cortical circuitry development and schizophrenia. Curr. Opin. Genet. Dev. 21, 262-270. doi: 10.1016/j.gde.2010.12.010

Rubenstein, J. L. (2011). Annual research review: development of the cerebral cortex: implications for neurodevelopmental disorders. J. Child Psychol. Psychiatry 52, 339-355. doi: 10.1111/j.1469-7610.2010.02307.x

Saha, B., Hari, P., Huilgol, D., and Tole, S. (2007). Dual role for LIM-homeodomain gene Lhx2 in the formation of the lateral olfactory tract. J. Neurosci. 27, 2290-2297. doi: 10.1523/JNEUROSCI.5571-06.2007 
Salter, M. W., and Beggs, S. (2014). Sublime microglia: expanding roles for the guardians of the CNS. Cell 158, 15-24. doi: 10.1016/j.cell.2014.06.008

Sato, Y., Hirata, T., Ogawa, M., and Fujisawa, H. (1998). Requirement for earlygenerated neurons recognized by monoclonal antibody lot 1 in the formation of lateral olfactory tract. J. Neurosci. 18, 7800-7810.

Schafer, D. P., Lehrman, E. K., Kautzman, A. G., Koyama, R., Mardinly, A. R., Yamasaki, R., et al. (2012). Microglia sculpt postnatal neural circuits in an activity and complement-dependent manner. Neuron 74, 691-705. doi: 10.1016/j.neuron.2012.03.026

Schafer, D. P., Lehrman, E. K., and Stevens, B. (2013). The "quad-partite" synapse: microglia-synapse interactions in the developing and mature CNS. Glia 61, 24-36. doi: 10.1002/glia.22389

Schlegelmilch, T., Henke, K., and Peri, F. (2011). Microglia in the developing brain: from immunity to behaviour. Curr. Opin. Neurobiol. 21, 5-10. doi: 10.1016/j.conb.2010.08.004

Schulz, C., Gomez Perdiguero, E., Chorro, L., Szabo-Rogers, H., Cagnard, N., Kierdorf, K., et al. (2012). A lineage of myeloid cells independent of Myb and hematopoietic stem cells. Science 336, 86-90. doi: 10.1126/science.1219179

Serafini, T., Colamarino, S. A., Leonardo, E. D., Wang, H., Beddington, R., Skarnes, W. C., et al. (1996). Netrin-1 is required for commissural axon guidance in the developing vertebrate nervous system. Cell 87, 1001-1014. doi: 10.1016/S00928674(00)81795-X

Serafini, T., Kennedy, T. E., Galko, M. J., Mirzayan, C., Jessell, T. M., and Tessier-Lavigne, M. (1994). The netrins define a family of axon outgrowthpromoting proteins homologous to C. elegans UNC-6. Cell 78, 409-424. doi: 10.1016/0092-8674(94)90420-0

Shu, T., Butz, K. G., Plachez, C., Gronostajski, R. M., and Richards, L. J. (2003a). Abnormal development of forebrain midline glia and commissural projections in Nfia knock-out mice. J. Neurosci. 23, 203-212.

Shu, T., Li, Y., Keller, A., and Richards, L. J. (2003b). The glial sling is a migratory population of developing neurons. Development 130, 2929-2937. doi: $10.1242 /$ dev.00514

Shu, T., and Richards, L. J. (2001). Cortical axon guidance by the glial wedge during the development of the corpus callosum. J. Neurosci. 21, 2749-2758.

Shu, T., Sundaresan, V., Mccarthy, M. M., and Richards, L. J. (2003c). Slit2 guides both precrossing and postcrossing callosal axons at the midline in vivo. J. Neurosci. 23, 8176-8184.

Sierra, A., Abiega, O., Shahraz, A., and Neumann, H. (2013). Janus-faced microglia: beneficial and detrimental consequences of microglial phagocytosis. Front. Cell. Neurosci. 7:6. doi: 10.3389/fncel.2013.00006

Sierra, A., Encinas, J. M., Deudero, J. J., Chancey, J. H., Enikolopov, G., OverstreetWadiche, L. S., et al. (2010). Microglia shape adult hippocampal neurogenesis through apoptosis-coupled phagocytosis. Cell Stem Cell 7, 483-495. doi: 10.1016/j.stem.2010.08.014

Silver, J., Edwards, M. A., and Levitt, P. (1993). Immunocytochemical demonstration of early appearing astroglial structures that form boundaries and pathways along axon tracts in the fetal brain. J. Comp. Neurol. 328, 415-436. doi: 10.1002/cne.903280308

Silver, J., Lorenz, S. E., Wahlsten, D., and Coughlin, J. (1982). Axonal guidance during development of the great cerebral commissures: descriptive and experimental studies, in vivo, on the role of preformed glial pathways. J. Comp. Neurol. 210, 10-29. doi: 10.1002/cne.902100103

Silver, J., and Ogawa, M. Y. (1983). Postnatally induced formation of the corpus callosum in acallosal mice on glia-coated cellulose bridges. Science 220, 1067-1069. doi: 10.1126/science.6844928

Soriano, E., Cobas, A., and Fairen, A. (1986). Asynchronism in the neurogenesis of GABAergic and non-GABAergic neurons in the mouse hippocampus. Brain Res. 395, 88-92. doi: 10.1016/0165-3806(86)90134-3

Soriano, E., Cobas, A., and Fairen, A. (1989). Neurogenesis of glutamic acid decarboxylase immunoreactive cells in the hippocampus of the mouse. I: regio superior and regio inferior. J. Comp. Neurol. 281, 586-602. doi: $10.1002 /$ cne. 902810408

Squarzoni, P., Oller, G., Hoeffel, G., Pont-Lezica, L., Rostaing, P., Low, D., et al. (2014). Microglia modulate wiring of the embryonic forebrain. Cell Rep. 8, 1271-1279. doi: 10.1016/j.celrep.2014.07.042

Sretavan, D. W., Pure, E., Siegel, M. W., and Reichardt, L. F. (1995). Disruption of retinal axon ingrowth by ablation of embryonic mouse optic chiasm neurons. Science 269, 98-101. doi: 10.1126/science. 7541558
Sugisaki, N., Hirata, T., Naruse, I., Kawakami, A., Kitsukawa, T., and Fujisawa, H. (1996). Positional cues that are strictly localized in the telencephalon induce preferential growth of mitral cell axons. J. Neurobiol. 29, 127-137.

Super, H., Martinez, A., Del Rio, J. A., and Soriano, E. (1998). Involvement of distinct pioneer neurons in the formation of layer-specific connections in the hippocampus. J. Neurosci. 18, 4616-4626.

Super, H., and Soriano, E. (1994). The organization of the embryonic and early postnatal murine hippocampus. II. Development of entorhinal, commissural, and septal connections studied with the lipophilic tracer DiI. J. Comp. Neurol. 344, 101-120. doi: 10.1002/cne.903440108

Sur, M., and Rubenstein, J. L. (2005). Patterning and plasticity of the cerebral cortex. Science 310, 805-810. doi: 10.1126/science.1112070

Sussel, L., Marin, O., Kimura, S., and Rubenstein, J. L. (1999). Loss of Nkx2.1 homeobox gene function results in a ventral to dorsal molecular respecification within the basal telencephalon: evidence for a transformation of the pallidum into the striatum. Development 126, 3359-3370.

Swinnen, N., Smolders, S., Avila, A., Notelaers, K., Paesen, R., Ameloot, M., et al. (2013). Complex invasion pattern of the cerebral cortex bymicroglial cells during development of the mouse embryo. Glia 61, 150-163. doi: 10.1002/glia.22421

Takiguchi-Hayashi, K., Sekiguchi, M., Ashigaki, S., Takamatsu, M., Hasegawa, H., Suzuki-Migishima, R., et al. (2004). Generation of reelin-positive marginal zone cells from the caudomedial wall of telencephalic vesicles. J. Neurosci. 24, 2286-2295. doi: 10.1523/JNEUROSCI.4671-03.2004

Tessier-Lavigne, M., Placzek, M., Lumsden, A. G., Dodd, J., and Jessell, T. M. (1988). Chemotropic guidance of developing axons in the mammalian central nervous system. Nature 336, 775-778. doi: 10.1038/336775a0

Tissir, F., Bar, I., Jossin, Y., De Backer, O., and Goffinet, A. M. (2005). Protocadherin Celsr3 is crucial in axonal tract development. Nat. Neurosci. 8, 451-457. doi: $10.1038 / \mathrm{nn} 1428$

Tissir, F., and Goffinet, A. M. (2003). Reelin and brain development. Nat. Rev. Neurosci. 4, 496-505. doi: 10.1038/nrn1113

Tissir, F., Ravni, A., Achouri, Y., Riethmacher, D., Meyer, G., and Goffinet, A. M. (2009). DeltaNp73 regulates neuronal survival in vivo. Proc. Natl. Acad. Sci. U.S.A. 106, 16871-16876. doi: 10.1073/pnas.0903191106

Tomioka, N., Osumi, N., Sato, Y., Inoue, T., Nakamura, S., Fujisawa, H., et al. (2000). Neocortical origin and tangential migration of guidepost neurons in the lateral olfactory tract. J. Neurosci. 20, 5802-5812.

Tremblay, M. E., Lowery, R. L., and Majewska, A. K. (2010). Microglial interactions with synapses are modulated by visual experience. PLoS Biol. 8:e1000527. doi: 10.1371/journal.pbio.1000527

Trousse, F., Poluch, S., Pierani, A., Dutriaux, A., Bock, H. H., Nagasawa, T., et al. (2014). CXCR7 receptor controls the maintenance of subpial positioning of Cajal-Retzius cells. Cereb. Cortex. doi: 10.1093/cercor/bhu164. [Epub ahead of print].

Tuttle, R., Nakagawa, Y., Johnson, J. E., and O’leary, D. D. (1999). Defects in thalamocortical axon pathfinding correlate with altered cell domains in Mash-1-deficient mice. Development 126, 1903-1916.

Uemura, M., Nakao, S., Suzuki, S. T., Takeichi, M., and Hirano, S. (2007). OLProtocadherin is essential for growth of striatal axons and thalamocortical projections. Nat. Neurosci. 10, 1151-1159. doi: 10.1038/nn1960

Ueno, M., Fujita, Y., Tanaka, T., Nakamura, Y., Kikuta, J., Ishii, M., et al. (2013). Layer V cortical neurons require microglial support for survival during postnatal development. Nat. Neurosci. 16, 543-551. doi: 10.1038/ nn.3358

Van Rooijen, N., Bakker, J., and Sanders, A. (1997). Transient suppression of macrophage functions by liposome-encapsulated drugs. Trends Biotechnol. 15, 178-185. doi: 10.1016/S0167-7799(97)01019-6

Varvel, N. H., Grathwohl, S. A., Baumann, F., Liebig, C., Bosch, A., Brawek, B., et al. (2012). Microglial repopulation model reveals a robust homeostatic process for replacing CNS myeloid cells. Proc. Natl. Acad. Sci. U.S.A. 109, 18150-18155. doi: 10.1073/pnas.1210150109

Verney, C., Monier, A., Fallet-Bianco, C., and Gressens, P. (2010). Early microglial colonization of the human forebrain and possible involvement in periventricular white-matter injury of preterm infants. J. Anat. 217, 436-448. doi: 10.1111/j.1469-7580.2010.01245.x

Villar-Cervino, V., Molano-Mazon, M., Catchpole, T., Valdeolmillos, M., Henkemeyer, M., Martinez, L. M., et al. (2013). Contact repulsion controls the 
dispersion and final distribution of Cajal-Retzius cells. Neuron 77, 457-471. doi: 10.1016/j.neuron.2012.11.023

Wake, H., Moorhouse, A. J., Jinno, S., Kohsaka, S., and Nabekura, J. (2009). Resting microglia directly monitor the functional state of synapses in vivo and determine the fate of ischemic terminals. J. Neurosci. 29, 3974-3980. doi: 10.1523/JNEUROSCI.4363-08.2009

Wakselman, S., Bechade, C., Roumier, A., Bernard, D., Triller, A., and Bessis, A. (2008). Developmental neuronal death in hippocampus requires the microglial CD11b integrin and DAP12 immunoreceptor. J. Neurosci. 28, 8138-8143. doi: 10.1523/JNEUROSCI.1006-08.2008

Wang, L. C., Dani, J., Godement, P., Marcus, R. C., and Mason, C. A. (1995). Crossed and uncrossed retinal axons respond differently to cells of the optic chiasm midline in vitro. Neuron 15, 1349-1364. doi: 10.1016/08966273(95)90013-6

Wang, Y., Thekdi, N., Smallwood, P. M., Macke, J. P., and Nathans, J. (2002). Frizzled-3 is required for the development of major fiber tracts in the rostral CNS. J. Neurosci. 22, 8563-8573.

Wang, Y., Zhang, J., Mori, S., and Nathans, J. (2006). Axonal growth and guidance defects in Frizzled3 knock-out mice: a comparison of diffusion tensor magnetic resonance imaging, neurofilament staining, and genetically directed cell labeling. J. Neurosci. 26, 355-364. doi: 10.1523/JNEUROSCI.3221-05.2006

Williams, S. E., Mann, F., Erskine, L., Sakurai, T., Wei, S., Rossi, D. J., et al. (2003). Ephrin-B2 and EphB1 mediate retinal axon divergence at the optic chiasm. Neuron 39, 919-935. doi: 10.1016/j.neuron.2003.08.017

Wright, A. G., Demyanenko, G. P., Powell, A., Schachner, M., Enriquez-Barreto, L., Tran, T. S., et al. (2007). Close homolog of L1 and neuropilin 1 mediate guidance of thalamocortical axons at the ventral telencephalon. J. Neurosci. 27, 13667-13679. doi: 10.1523/JNEUROSCI.2888-07.2007
Yoshida, M., Assimacopoulos, S., Jones, K. R., and Grove, E. A. (2006). Massive loss of Cajal-Retzius cells does not disrupt neocortical layer order. Development 133, 537-545. doi: 10.1242/dev.02209

Yun, K., Garel, S., Fischman, S., and Rubenstein, J. L. (2003). Patterning of the lateral ganglionic eminence by the Gsh1 and Gsh2 homeobox genes regulates striatal and olfactory bulb histogenesis and the growth of axons through the basal ganglia. J. Comp. Neurol. 461, 151-165. doi: 10.1002/cne.10685

Zhan, Y., Paolicelli, R. C., Sforazzini, F., Weinhard, L., Bolasco, G., Pagani, F., et al. (2014). Deficient neuron-microglia signaling results in impaired functional brain connectivity and social behavior. Nat. Neurosci. 17, 400-406. doi: 10.1038/nn.3641

Zhou, L., Bar, I., Achouri, Y., Campbell, K., De Backer, O., Hebert, J. M., et al. (2008). Early forebrain wiring: genetic dissection using conditional Celsr3 mutant mice. Science 320, 946-949. doi: 10.1126/science.1155244

Zhou, L., Qu, Y., Tissir, F., and Goffinet, A. M. (2009). Role of the atypical cadherin Celsr3 during development of the internal capsule. Cereb. Cortex 19 (Suppl. 1), i114-i119. doi: 10.1093/cercor/bhp032

Conflict of Interest Statement: The authors declare that the research was conducted in the absence of any commercial or financial relationships that could be construed as a potential conflict of interest.

Copyright (c) 2015 Squarzoni, Thion and Garel. This is an open-access article distributed under the terms of the Creative Commons Attribution License (CC BY). The use, distribution or reproduction in other forums is permitted, provided the original author(s) or licensor are credited and that the original publication in this journal is cited, in accordance with accepted academic practice. No use, distribution or reproduction is permitted which does not comply with these terms. 